\title{
The Erymnochelys group of turtles (Pleurodira, Podocnemididae) in the Eocene of Europe: New taxa and paleobiogeographical implications
}

\author{
Adán Pérez-García, France de Lapparent de Broin, and Xabier Murelaga
}

\begin{abstract}
The Erymnochelys group is a lineage of Erymnochelyinae, pleurodiran turtles that originated in Africa, with a fossil record extending from the Late Cretaceous. It is currently represented by a single species, the Malagasy Erymnochelys madagascariensis. Information on most of its fossil representatives is sparse. In fact, the oldest unambiguous generic determinations heretofore established within the group are those of Turkanemys and Kenyemys, both from the latest Miocene-Pliocene of Kenya. The description and illustration of the French middle Eocene species 'aff. Erymnochelys' eremberti is completed here, and a diagnosis for this species is proposed for the first time. It is attributed to a new genus, Eocenochelus, the first genus of the Erymnochelys group defined outside of Africa. Eocenochelus is also recognized in the European lower and upper Eocene record by two new species, Eocenochelus lacombianus and Eocenochelus farresi, respectively. Therefore, Eocenochelus is a taxon with a wide distribution in Europe during the Eocene and is relatively diverse. This is also the case with the continental Neochelys, the only other podocnemidid genus so far recognized in the European Paleogene record. Exclusively identified in coastal deposits, Eocenochelus is the only known form of the Erymnochelys group found in marginal marine sediments. Its anatomical adaptations probably facilitated the spread from Africa to Europe.
\end{abstract}

Adán Pérez-García. Grupo de Biología Evolutiva, Facultad de Ciencias, Universidad Nacional de Educación a Distancia, Paseo de la Senda del Rey 9, 28040 Madrid, Spain. paleontologo@gmail.com France de Lapparent de Broin. Centre de Recherche sur la Paléodiversité et les Paléoenvironnements, Muséum national d'Histoire naturelle, 57 rue Cuvier, CP 38, 75231 Paris cedex 5, France.

france.lapparent@sfr.fr

Xabier Murelaga. Departamento de Estratigrafía y Paleontología, Facultad de Ciencia y Tecnología, Universidad del País Vasco, UPV/EHU, Apartado 644, 48080 Bilbao, Spain. xabier.murelaga@ehu.eus

http://zoobank.org/1D985176-5AD4-45FF-8BD7-C4AD17C7DE52

Pérez-García, Adán, de Lapparent de Broin, France, and Murelaga, Xabier. 2017. The Erymnochelys group of turtles (Pleurodira, Podocnemididae) in the Eocene of Europe: New taxa and paleobiogeographical implications. Palaeontologia Electronica 20.1.14A: $1-28$

palaeo-electronica.org/content/2017/1798-erymnochelys-group-in-europe

Copyright: @ April 2017 Society of Vertebrate Paleontology. This is an open access article distributed under the terms of the Creative Commons Attribution License, which permits unrestricted use, distribution, and reproduction in any medium, provided the original author and source are credited.

creativecommons.org/licenses/by/4.0/ 
Keywords: Side-necked turtles; Erymnochelyinae; African lineage; new genus; new species

\section{INTRODUCTION}

\section{The Erymnochelys Group in Europe}

Erymnochelyinae (sensu Lapparent de Broin, 2000a, 2000b; Pérez-García and Lapparent de Broin, 2015) is a lineage of podocnemidid turtles (Pleurodira) currently represented by a single taxon, the Malagasy Erymnochelys madascariensis (Grandidier, 1867). It belongs to the Erymnochelys group, an erymnochelyine clade in which the gulars are in contact posteromedially, and located posteriorly to a reduced intergular that they frame (see Broin, 1988; Lapparent de Broin, 2000a, 2000b; Lapparent de Broin in Merle, 2008; Pérez-García and Lapparent de Broin, 2015). Erymnochelyinae is a lineage originating in Africa, where it is known at least from the late Cretaceous only by fragmentary specimens (Broin et al., 1974;
Lapparent de Broin, 2000b, 2003a; Gaffney and Forster, 2003). However, no taxa of Erymnochelyinae have been defined in pre-Eocene levels (Figure 1).

Until now, no unambiguous genus of the Erymnochelys group has been named either outside Africa or in any older levels than those of the latest Miocene (Lothagam 1, in Kenya), where Turkanemys pattersoni and Kenyemys williamsi were described. A French specimen from Saint-Germain-en-Laye was first cited by Taugourdeau (1965), and attributed to a new species, Podocnemys [sic] eremberti. This new specific name, only mentioned in the title of an abstract in anticipation of a future note, was not accompanied by a description or definition that states in words any characters purported to differentiate the taxon, as required by the International Code of Zoological

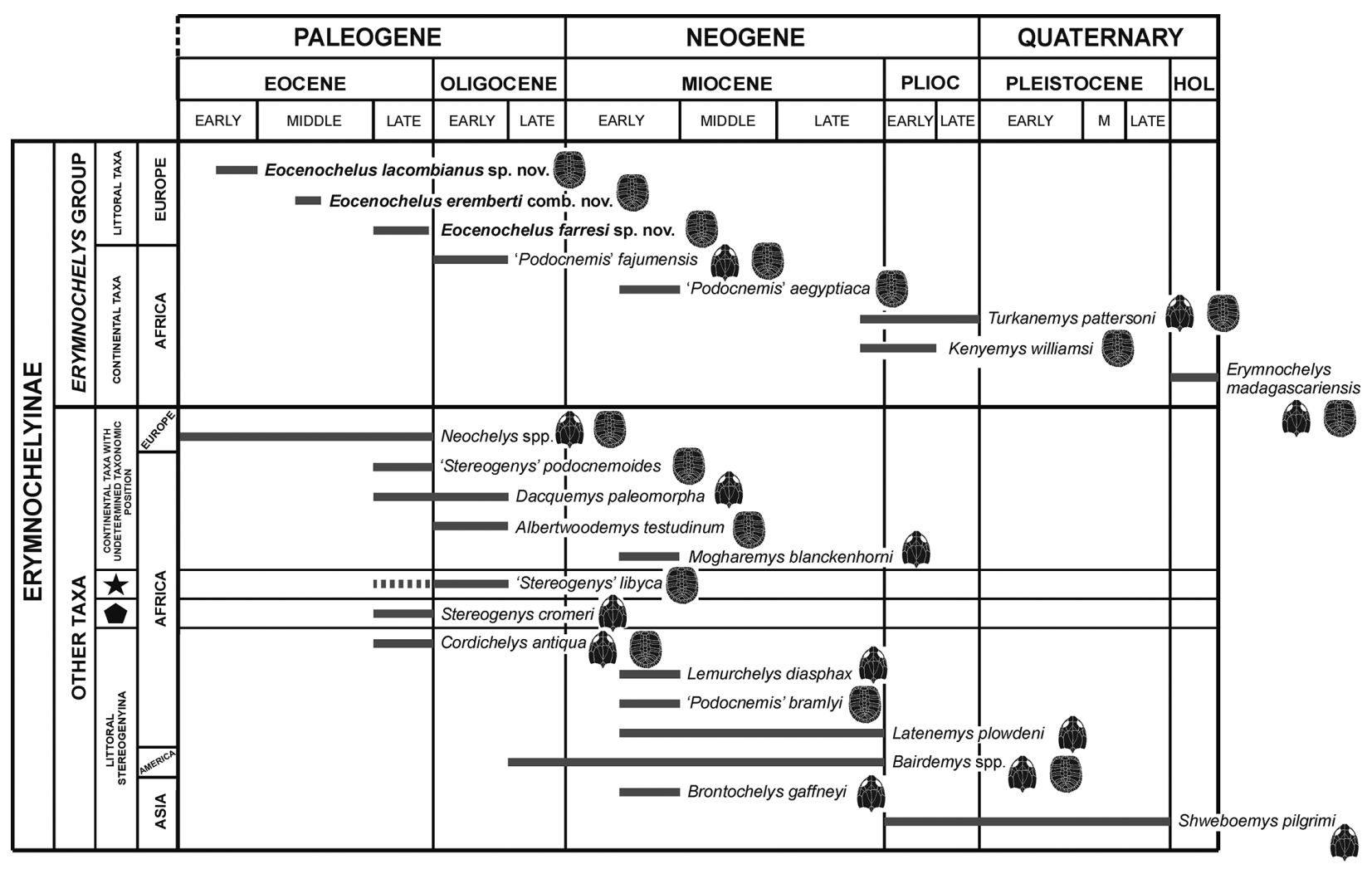

FIGURE 1. Stratigraphic and paleobiogeographical distributions of the currently accepted members of Erymnochelyinae, including the European taxa described here, i.e., the representatives of the new genus Eocenochelus, belonging to the Erymnochelys group. The shell and skull symbols accompanying the name of each taxon indicate which of these elements are known. The star indicates continental Stereogenyina, and the pentagon indicates continental or littoral Stereogenyina. 


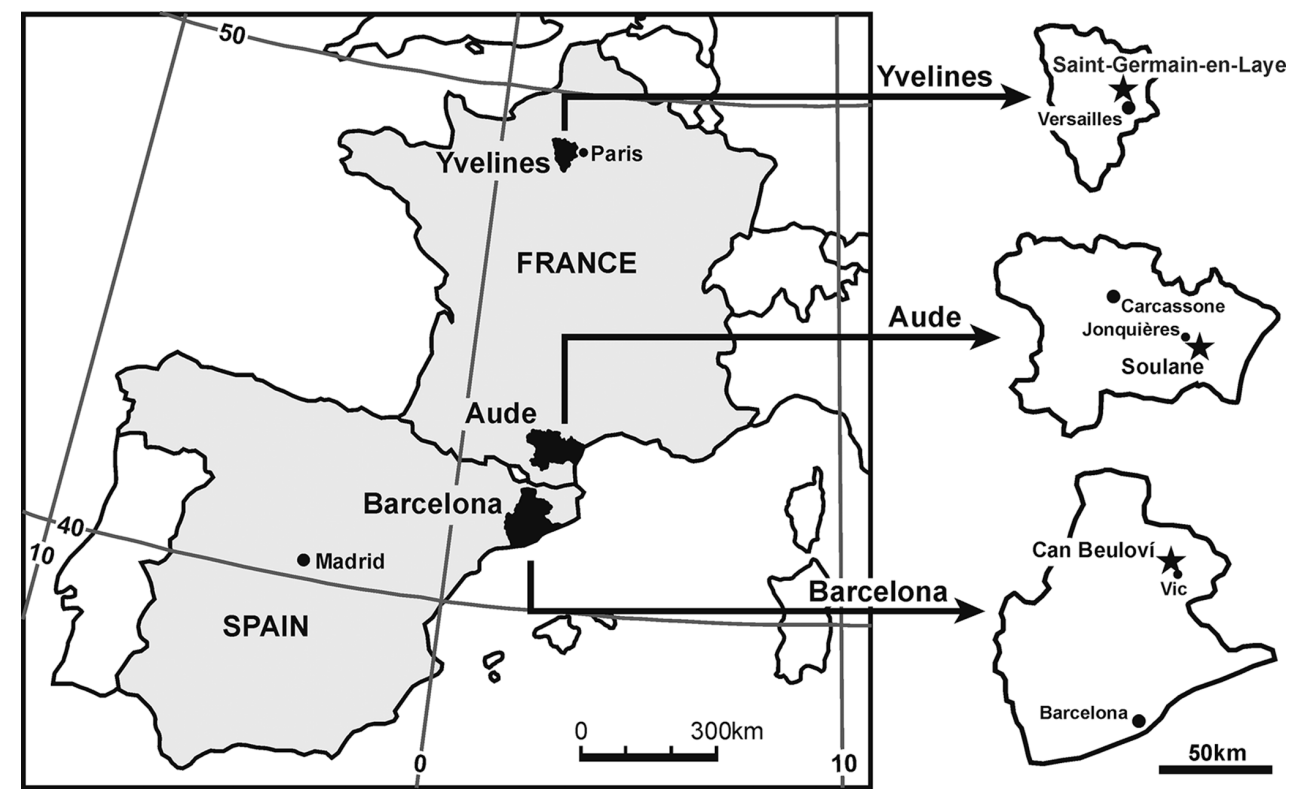

FIGURE 2. Geographic locations of the type localities of the European Eocene representatives of the podocnemidid Eocenochelus gen. nov.: Soulane (Jonquières, Aude, France), type locality of the lower Eocene (Ypresian) Eocenochelus lacombianus sp. nov.; Saint-Germain-en-Laye (Yvelines, Île-de-France, France), type locality of the middle Eocene (Lutetian) Eocenochelus eremberti comb. nov.; Can Beuloví (Sobremunt, Barcelona, Spain), type locality of the upper Eocene (Priabonian) Eocenochelus farresi sp. nov.

Nomenclature (Article 13.1.) for any taxon described after 1930. Thus, this taxon is a nomen nudum as no figure was provided. Broin (1977) validated that species and reattributed it to Erymnochelys, briefly describing the skull, without illustration, but comparing it to those of the most representative podocnemidids at that time: Podocnemis spp., Peltocephalus dumerilianus (Schweigger, 1812), Dacquemys paleomorpha, Erymnochelys madagascariensis and Neochelys arenarum Broin, 1977. Broin (1977) also established some of the characters of the shell, emphazing its affinity with Er. madagascariensis. Subsequent papers refuted its attribution to Erymnochelys, suggesting instead that it was a very closely related, but undefined, new genus. This specimen was referred to as 'aff. Erymnochelys' eremberti (Lapparent de Broin in Merle, 2008; Pérez-García and Lapparent de Broin, 2015). Its detailed anatomy is documented here, so that the oldest genus of the Erymnochelys group now is defined as Eocenochelus gen. nov.

European specimens identified as closely related to Erymnochelys are here recognized not only in France, but also in Italy and Spain based on unpublished shells (Righi and Delfino, 2003; Murelaga et al., 2007) found in littoral or deltaic beds. The Spanish specimen was found in upper Eocene (Priabonian) levels of Can Beulovi (Osona,
Catalonia; Figure 2), whereas an almost complete shell comes from the lower Eocene (early Ypresian) French locality of Soulane (Aude; Figure 2). Both specimens are studied and named here. The French specimen is attributable to a new species, Eocenochelus lacombianus sp. nov., and is the oldest defined representative of the Erymnochelys group. The Spanish specimen is also attributed to a new species, Eocenochelus farresi sp. nov., which is the more recent representative of the genus. Eocenochelus is recognized as a diverse coastal genus, with a wide European Eocene temporal distribution. The European erymnochelyine Neochelys is a co-existing taxon, but it is a continental form, found in different localities, corresponding to different sedimentary environments (Lapparent de Broin, 2003b; Pérez-García and Lapparent de Broin, 2013).

\section{Diversity of Erymnochelyinae}

Several species of Erymnochelyinae have been defined in Africa from the late Eocene. The oldest defined representatives are part of the mixed continental and marine fauna of the Fayum depression (Western desert of Egypt): Cordichelys antiqua (Andrews, 1903) and Stereogenys cromeri Andrews, 1901, from the upper Eocene (Priabonian) Qasr el-Sagha Formation; 'Stereogenys' podocnemoides Reinach, 1903, probably from the 
same formation; Dacquemys paleomorpha Williams, 1954, from the upper Eocene Qasr el-Sagha or Birket Qarun formations and from the early Oligocene lower member of the Jebel el-Qatrani Formation; and Albertwoodemys testudinum Gaffney et al., 2011, 'Podocnemis' fajumensis Andrews, 1903 and 'Stereogenys' libyca Andrews, 1903, from the lower Oligocene Jebel el-Quatrani Formation (the last species may also have been present in the Qasr el-Sagha Formation). Three taxa are known from the nearby Egyptian Qattara Depression, from the lower Miocene (Burdigalian) Moghara Formation: Lemurchelys diasphax Gaffney, Meylan, Wood, Simons and Almeida Campos, 2011, 'Podocnemis' bramlyi Fourteau, 1920 and 'Podocnemis' aegyptiaca Andrews, 1900. Mogharemys blanckenhorni (Dacqué, 1912) is from the lower Miocene levels of the same Moghara area and probably came from the same formation, as is probably also the case with Latenemys plowdeni Gaffney et al., 2011. Turkanemys pattersoni Wood, 2003 and Kenyemys williamsi Wood, 1983 come from the latest Miocene-Pliocene continental deposits (latest Messinian to Piacenzian) of Turkana Lake in Kenya ( $T$. pattersoni from Lothagam 1 and 3, Ekora and Kanapoi; and K. williamsi from Lothagam 1) (Lapparent de Broin, 2000b; Gaffney et al., 2011) (Figure 1).

As it has been evidenced by the fossil record, during transgressive episodes not allowing a continental contact, several representatives of Erymnochelyinae migrated from Africa to other continents by various sea ways, such as following the coasts or crossing short sea arms, helped by favorable currents. These forms lack true large and rigid flippers supporting open sea locomotion and transoceanic migrations (as for the true marine turtles, i.e., the derived chelonioids and the dermochelyoids). However, they show a hyaline tolerance, being morphologically partly adapted to marine locomotion (Renous et al., 2008). Through this means, Erymnochelyinae spread to America where it is represented by several species of Bairdemys Gaffney and Wood, 2002, identified from the upper Oligocene (early Chattian) record of South Carolina and the Mio-Pliocene of Maryland, Puerto Rico and Venezuela (Gaffney et al., 2011; Weems and Knight, 2013; Ferreira et al., 2015). In Western Asia, Erymnochelyinae is represented by the lower Miocene (Burdigalian) species Brontochelys gaffneyi (Wood, 1970) from Pakistan, and the PlioPleistocene Shweboemys pilgrimi Swinton, 1939 from Myanmar (Burma) (Wood, 1970; Gaffney et al., 2011; Barbière and Marivaux, 2015), species which might also have spread from Africa, following the coasts. Few localities with turtles have been identified from the Cenozoic of Africa, most of them being epicontinental deposits with a mixed littoralcontinental fauna, and very few of them are sites older than the upper Eocene Fayum localities (Lapparent de Broin, 2000b).

The Gondwanic origin of the Erymnochelyinae is demonstrated by its fossil record, and also by its belonging to Pelomedusoides, a clade that originated in the earliest Cretaceous in the linked continents of Africa and South America. Despite this fact, the oldest Erymnochelyinae members so far defined are European forms. In fact, this lineage is relatively abundant and diverse in the European Eocene record. Neochelys Bergounioux, 1954 is a genus restricted to Europe, being represented by several continental species identified in lower, middle and upper Eocene levels from several countries (Pérez-García and Lapparent de Broin, 2013, 2015; Cadena, 2015a) (Figure 1). Another form was defined in the European Eocene record: 'aff. Erymnochelys' eremberti (Broin, 1977) (sensu Lapparent de Broin in Merle, 2008; Pérez-García and Lapparent de Broin, 2015) from the middle Eocene (Lutetian) of Saint-Germain-en-Laye (Île-deFrance, France) (Figure 2). Its holotype and only known specimen consists of the skull, lower jaw and postcranial elements, including the nearly complete plastron and the partially preserved, but reconstructed, carapace. This incompletely described species is part of the Erymnochelys group. 'Aff. Erymnochelys' eremberti is the only member of this group defined outside of Africa so far, the other recognized representatives being 'Podocnemis' fajumensis (a species recently justified as belonging to a new and so far unpublished genus; see Pérez-García and Lapparent de Broin, 2015), 'Podocnemis' aegyptiaca, Turkanemys pattersoni, Kenyemys williamsi and the extant Er. madagascariensis (Pérez-García and Lapparent de Broin, 2015). The shells of all of them are known and all possess the determinant reduced intergular character. 'Podocnemis' fajumensis and T. pattersoni are the only African representatives of the group also represented by the skull. Many indetermined erymnochelyine specimens have been reported in other African localities (Lapparent de Broin, 2000a, 2000b). The oldest specimens attributed to the Erymnochelys group are poorly known and indeterminate forms from the continental Senonian of lbeceten (Niger), probably those from the Albian-Senonian or Campanian-Maastrichtian of Wadi Abou Hashim area (Sudan), and 
the Maastrichtian aff. Erymnochelys sp. from the Berivotra region (Madagascar) (Broin et al., 1974; Lapparent de Broin, 2000b; Gaffney and Forster, 2003; Klein et al., in press). Poorly defined members of this group have also been found in the lower Oligocene of Taqah (Oman), in correlative levels to those of the Jebel el-Quatrani Fm. (Thomas et al., 1991); in the lower Miocene (Burdigalian) of Auchas and Arrisdrift (Namibia) and of Karungu (Victoria Lake, Kenya); in the upper Miocene-lower Pliocene (Messinian-Placenzian) of the Sinda-Mohari beds of the Democratic Republic of Congo; and, probably, in the upper Pliocene of Kaiso Village (Uganda) (Lapparent de Broin, 2000b).

\section{Littoral Adaptations}

Among the Euro-African Erymnochelyinae mentioned above, several taxa do not belong to the Erymnochelys group. Their intergular is long and separates the gulars as in the oldest Pleurodira. Some of them show a "littoral shell pattern," which is a less protective shell than that found in the continental-amphibious taxa, but better adapted for swimming. This hydrodynamic shape facilitates the flow of water along the shell borders and gives more space for their limbs, developed as paddles (Lapparent de Broin et al., 1996; Renous et al., 2008). In this sense, two members of the Stereogenyina (sensu Gaffney et al., 2011) possess a shortened anterior shell and a narrower plastron. They are Cordichelys antiqua and Bairdemys spp. The Priabonian C. antiqua and the Oligocene Bairdemys healeyorum Weems and Knight, 2013 possess a short and wide nuchal plate, anteriorly notched, and a slightly domed and cordiform carapace. The more recent late Miocene-early Pliocene Bairdemys venezuelensis (Wood and Díaz de Gamero, 1971) shares these features except for a slightly elongated nuchal. Cordichelys antiqua and $B$. healeyorum have short anterior peripherals, with a rounded and short anterior border (being more elongated in Bairdemys venezuelensis). All these taxa have short axillary notches framing a short and wide (relative to its length) anterior plastral lobe that shows anteriorly converging lateral borders. In contrast, the posterior plastral lobe of these taxa is as narrow as in basal Pelomedusoides (e.g., the Early Cretaceous Teneremys lapparenti Broin, 1980), because they are not secondarily widened (Lapparent de Broin et al., 2007). This lobe has notably convergent posterior lateral borders and a wide inguinal notch.
These littoral adaptations that are described for the shell might serve to facilitate the posterior limb movement in these turtles, which do not possess true marine flippers, just as the enlarged axillary notches facilitate the movement of the anterior limbs. Weems and Knight (2013) showed that the femur extremity of Bairdemys healeyorum is strongly similar to that of the trionychids, and its humerus head is oriented as in sea turtles, recognizing an anterior and posterior combination of limb functions strikingly similar to that of Carettochelys insculpta Ramsay, 1886. The carettochelyid flipper morphotype is that of a freshwater to brackish turtle, with elongated metapods and digits composing a flexible paddle (being rigid in the transoceanic marine chelonoids and dermochelyoids), and with the humerus as long as the femur (not longer than it as in these true marine forms). Beside its capacity for dispersion by continental freshwater environments, Carettochelys can follow the coasts and spread this way, reaching new continental territories (Lapparent de Broin, 2000b). Trionychids also eventually practise this migratory method (Lapparent de Broin, 2000b), helped by their comparably flexible paddles to those of Carettochelys, but being less derived. Without an elongated great trochanter as well as having an acute scapula angle (ca. $70^{\circ}$ ) and a femur longer than the humerus, trionychids are not capable of an anterior limb synchrony, present in Carettochelys, chelonoids and dermochelyoids (Renous et al., 2008). The angle between the scapula and the acromion of Bairdemys (ca. $90^{\circ}$ ) is similar to that of Carettochelys $\left(92^{\circ}\right)$, and slightly lower than that of Lepidochelys Fitzinger, $1843\left(95\right.$ to $100^{\circ}$ ) (Lepidochelys being the extant cheloniid with the less obtuse angle, being of $130^{\circ}$ in Chelonia Brongniart, 1800). Thus, the angle in Bairdemys is slightly higher than that in the freshwater Erymnochelys madagascariensis $\left(85^{\circ}\right)$. The Bairdemys humerus is not longer than the femur (as in Carettochelys), but it lacks the elongated great trochanter present in Carettochelys and in the marine turtles. In the absence of preservation of metapods, fingers (very elongated in the taxa with flippers) and coracoid (very elongated in the marine turtles) in Bairdemys, the detailed comparison cannot be done; however, its paddle pattern could be interpreted as intermediate between those of the trionychids and the carettochelyids. The eventual anterior paddles of Bairdemys, however, could have been less developed than in the above compared aquatic tolerant, hyaline turtles (except the trionychids), but more developed than in exclusively freshwater continental 
turtles. The hydrodynamic shape of the carapace of Bairdemys and the large plastral notches, support this interpretation. Some of these adaptations are also shared with some littoral bothremydids (Broin, 1980; Antunes and Broin, 1988; Gaffney et al., 2006).

Although their shells are unknown, the Stereogenyina Schweboemys pilgrimi, Brontochelys gaffneyi, Lemurchelys diasphax and Latenemys plowdeni are attributed to this group of the littoral Stereogenyina. They share with Cordichelys antiqua and Bairdemys spp. an apomorphic crushing secondary palate, a lower jaw with a widely extended triturating surface on each dentary side and a well-developed posterior symphysis notch. The palate is characterized by having the maxillopalatine triturating surfaces strongly widened from the anterior to the posterior areas. The lateral maxillae and palatine borders posteriorly converge on the fossa temporalis inferior. The medial borders of the maxillopalatine surfaces are parallel in the middle region, but posteriorly diverge up to the end of the secondary palate, more or less posteriorly to the choanae. In the Africano-Asiatic taxa, the secondary palate ends about the middle of the distance separating the anterior border of the fossa and the processus trochlearis pterygoidei. These taxa have a short pterygoid palatal length, posteriorly to the triturating surfaces showing lateral borders in the fossa inferior, parallel to the medial axis. In the case of Bairdemys, the ends of the triturating surfaces are located at the level of the processus trochlearis pterygoidei, except in Bairemys thalassica Ferreira, Rincón, Solórzano and Langer, 2015, where the lateral borders of the pteygoids diverge, posteriorly to the secondary palate, on a short length anteriorly to the processus trochlearis pterygoidei. In addition, these Stereogenyina have a short snout and a do not have a widened interorbital space. 'Podocnemis' bramlyi, without a known skull, can also be added to this group because of its plastral pattern (coming from the same area and age as Lemurchelys diasphax).

In contrast, other Euro-African erymnochelyine taxa not belonging to the Erymnochelys group do not possess these littoral adaptations. As in the members of the Erymnochelys group, they reinforce the protection of the head, neck and limbs, as in many amphibious continental turtles, by various characters related to elongation of the anterior shell and plastron and the widening of the plastral lobes, generating narrower axillary and inguinal notches. These taxa are Neochelys spp., 'Stereogenys' libyca, Albertwoodemys testudinum and 'Ste- reogenys' podocnemoides. 'Stereogenys' libyca is separated from the Shweboemys group sensu Broin (1988) and Lapparent de Broin (2000b) (i.e., Sterogenyina sensu Gaffney et al., 2011; Cadena, 2015a; Ferreira et al., 2015) by the continental shell pattern. No skull attributed to 'Stereogenys' libyca is known. As Gaffney et al. (2011) indicated, the only indisputably material attributable to the type species of Stereogenys (i.e., Stereogenys cromeri) are cranial remains (the type material of this taxon corresponding to a nearly complete skull, preserving the jaws); therefore, the species 'Stereogenys' libyca belongs to an undefined genus currently under study. The observation of published and unpublished plates and partial shells of 'Stereogenys' libyca, as well as the finding and first hand study of the supposedly lost holotype of this species (see Pérez-García, 2014), allow us to support the hypothesis that the shells previously attributed to Stereogenys cromeri (see, for example, Andrews, 1906) actually correspond to 'Stereogenys' libyca, as was previously proposed by Gaffney et al. (2011). The shell of 'Stereogenys' libyca shows apomorphic features such as the absence of the first neural and a pentagonal first vertebral; a particular intergular/humerals/pectorals configuration; and strong widening of the plastal lobes, fully reducing the axillary and inguinal notches in ventral view. Thus, its shell is more domed than that of Cordichelys antiqua, being similar to that of the box-turtle Pelusios Wagler, 1830. This morphology is unknown for the other shells from the Fayum depression.

The skull of Stereogenys cromeri possessed a secondary palate that suggested an affinity of this genus with the taxa of the 'Shweboemys group' of Broin (1988) (i.e., Sterogenyina sensu Gaffney et al., 2011; Cadena, 2015a; Ferreira et al., 2015). Even so, its palate is recognized here as different from that of the 'Cordichelys-Bairdemys' morphotype present in all the other members of this littoral group, because its lateral palatine borders are not anteriorly divergent in the fossa inferior, but instead are parallel to the medial axis. This palate is much longer than that of the 'Cordichelys-Bairdemys' morphotype, with longer close and parallel medial borders. Medially, its posterior border is more abrupt, due to the development of short and straight to barely curved diverging borders. The corresponding lower jaw is more robust than in the 'Cordichelys-Bairdemys'morphotype, with a medially longer triturating surface (Andrews, 1903, 1906; Gaffney et al., 2011; Ferreira et al., 2015). This more caudally and medially expanded Ste- 
reogenys morphology seems to be that of a feeding strategy of possibly hard prey crushing, stronger than the other morphotype, more similar to that of the extant cheloniids (Carr, 1952; Pritchard, 1979) and bothremydids (Lapparent de Broin and Werner, 1998; Gaffney et al., 2006).

The systematic position of Dacquemys paleomorpha and Mogharemys blanckenhorni within Erymnochelyinae is not well known. These two taxa are only known by the skull. They do not belong to Stereogenyina (Figure 1). Their comparisons with the skulls of the members of the Erymnochelys group, also lacking a secondary palate, show possibilities of closer relationships.

Institutional abbreviations. MNHN.F, Paleontology Collection of the Muséum national d'Histoire naturelle, Paris, France; MGSB-GLV, Museu Geològic del Seminari de Barcelona-Geolab-Vic, Barcelona, Spain; NMK, National Museums of Kenya, Kenya.

\section{SYSTEMATIC PALEONTOLOGY}

Order CHELONII Latreille, 1800

Suborder PLEURODIRA Cope, 1864

Hyperfamily PELOMEDUSOIDES Cope, 1868

Superfamily PODOCNEMIDOIDEA Cope, 1868

Family PODOCNEMIDIDAE Cope, 1868

Subfamily ERYMNOCHELYINAE Broin, 1988

ERYMNOCHELYS GROUP sensu Pérez-García

and Lapparent de Broin, 2015

Genus Eocenochelus gen. nov.

Figures 3-8

zoobank.org/EC68A3B2-1722-4B33-B2F7-D6ED3011287B

1965 Podocnemys [sic]; Taugourdeau, p. 165.

1977 Erymnochelys; Broin, p. 89.

2008 'aff. Erymnochelys'; Lapparent de Broin in Merle, p. 154, pl. 9, figure 2.

2015 'aff. Erymnochelys'; Pérez-García and Lapparent de Broin, p. 915.

Type species. Erymnochelys eremberti Broin, 1977

Other included species. Eocenochelus lacombianus sp. nov.; Eocenochelus farresi sp. nov.

Etymology. This generic name refers to the Eocene, the Epoch in which this taxon lived, and chelus (Greek), turtle.

Distribution. Eocene (middle Ypresian to Priabonian) of Europe.

Diagnosis. Member of the Erymnochelys group with the following autapomorphies: Wide interorbital space, its minimum width being greater than the maximum length of the orbits; suborbital space markedly higher than the orbits; absence of a cheek emargination by the wide insertion of the jugal between the maxilla and the quadratojugal; medial concavity of the interparietal scute anterior margin; absence of overlap of the interparietal on the frontals; very robust mandible, with substraight labial margins, from the coronoid process to the fossa premaxillaris; high and robust dentary, wide in ventral view, without lateral border concavity; long mandibular symphysis, about $40 \%$ of the total length of the lower jaw, reaching the level of the foramen intermandibularis medius; and dorsal surface of the posterior border of the mandibular symphysis not vertical but constituting a slope of about $45^{\circ}$. It is distinguished from the other representatives of the Erymnochelys group by an exclusive combination of cranial characters: Short anterior snout, less than half of the length of the orbits (shared with T. pattersoni); wider than long nares (shared with 'Podocnemis' fajumensis and Erymnochelys madagascariensis); absence of premaxillary beak (shared with 'P.' fajumensis); absence of an interorbital longitudinal depression (shared with Turkanemys pattersoni, Er. madagascariensis and some specimens of ' $P$.' fajumensis); prefrontals shorter than frontals (shared with ' $P$.' fajumensis); transverse to slightly sinuous prefrontal-frontal contact, lacking a medial protusion (shared with T. pattersoni and Er. madagascariensis). It is also distinguished from the other representatives of the Erymnochelys group by an exclusive combination of shell characters: Absence of a partial or complete medial keel on the carapace (shared with ' $P$.' fajumensis, 'Podocnemis' aegyptiaca, Er. madagascariensis and most specimens of T. pattersoni); first vertebral heptagonal, with short latero-anterior margins, and as wide or wider than the nuchal plate (shared with 'P.' fajumensis, 'Podocnemis' aegyptiaca, T. pattersoni and Er. madagascariensis); second vertebral approximately as wide as the third, both scutes lacking wide lateral protrusions anterior to the limit between the pleural sulci (shared with 'P.' fajumensis, T. pattersoni, Kenyemys williamsi and Er. madagascariensis); first pair of marginals overlapping no more than half of the length of the lateral nuchal margins (shared with 'P.' fajumensis, 'P.' aegyptiaca, T. pattersoni and Er. madagascariensis); posterior plastral lobe narrower than the anterior (shared with $T$. pattersoni and Er. madagascariensis); absence of clear gular protrusions with parallel borders (shared with 'P.' aegyptiaca, T. pattersoni, Er. madagascariensis and some specimens of ' $P$.' fajumensis); relatively long intergular scute, reaching the anterior margin of the entoplastron or overlying its most anterior 

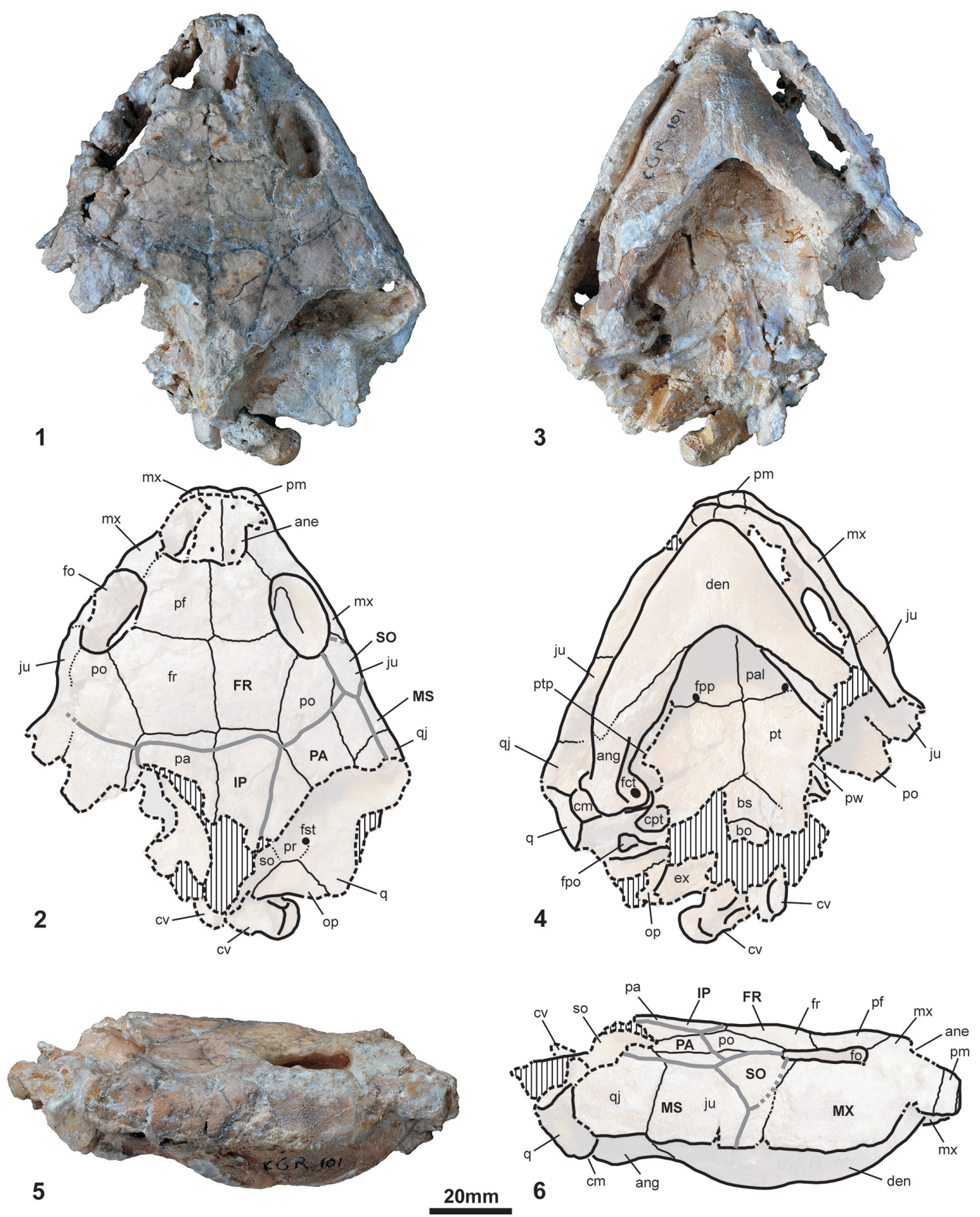

FIGURE 3. Skull of the holotype of Eocenochelus eremberti comb. nov., MNHN.F CGR 101, from the middle Eocene (Lutetian) of Saint-Germain-en-Laye (Yvelines, Île-de-France, France), in dorsal (1-2), ventral (3-4) and right lateral (5-6) views. Abbreviations: ane, apertura narium externa; ang, angular; bo, basioccipital; bs, basisphenoid; cm, condylus mandibularis; cpt, cavum pterygoidei; cv, cervical vertebra; den, dentary; ex, exoccipital; fct, foramen anterius chorda tympani; fo, fossa orbitalis; fpo, fenestra postotica; fpp, foramen palatinum posterius; fr, frontal; FR, frontal scute; fst, foramen stapedio-temporale; IP, interparietal scute; ju, jugal; MS, masseterian scute; mx, maxilla; MX, maxillary scute; op, opisthotic; pa, parietal; PA, parietal scute; pal, palatine; pf, prefrontal; pm, premaxilla; po, postorbital; pr, prootic; pt, pterygoid; ptp processus trochlearis pterygoidei; pw, pterygoid wing; q, quadrate; qj, quadratojugal; so, supraoccipital; SO, subocular scute. 
region (shared with 'P.' fajumensis, 'P.' aegyptiaca, T. pattersoni and some Er. madagascariensis); moderate length of the anal scutes, being shorter than two times the femoral length on the lateral borders of the xiphiplastra (shared with 'P.' fajumensis and ' $P$.' aegyptiaca); very short dorsal expansion of the plastral scute borders (shared with 'P.' aegyptiaca, T. pattersoni, K. williamsi and Er. madagascariensis).

Eocenochelus eremberti (Broin, 1977) comb. nov. Figures 3-6.49

1965 Podocnemys [sic] eremberti; Taugourdeau, p. 165: nomen nudum

1977 Erymnochelys eremberti; Broin, p. 89.

2008 'aff. Erymnochelys' eremberti; Lapparent de Broin in Merle, p. 154, pl. 9, figure 2.

2015 'aff. Erymnochelys' eremberti; Pérez-García and Lapparent de Broin, p. 915.

Holotype. MNHN.F CGR 101, a partial skeleton including the articulated skull with two anterior partial vertebrae, the fragmentary but partially reconstructed carapace, the relatively complete plastron, and various partial remains of the axial skeleton including a hyoid horn, the partial humerus, fragments of both scapulae, the two acromions with the partial glenoid part, a partial left coracoid, the partial femurs, the fragmentary right ilium, the left pubis and the left ischium (Figures 3-6.49).

Type locality and horizon. Grande Terrasse of the Chateau de Saint-Germain-en-Laye, SaintGermain-en-Laye, Yvelines, Île-de-France, France (Figure 2). "Banc Vert", upper part of the Milioles limestone, Abrard's zone 3, boundary below the "Marnes et Caillasses", upper middle Lutetian, middle Eocene (Taugourdeau, 1951; Aubry, 1986; Merle, 2008; Gély, 2009; White, 2013).

Diagnosis. Member of Eocenochelus with at least seven neurals, lacking medial contact of the sixth pair of costals (shared with Eocenochelus lacombianus but not with Eocenochelus farresi); long pubic scar, being almost five times longer than wide (not shared with Eo. lacombianus and not known in Eo. farresi); poorly developed posterior branch of the ischiatic scar, the distance from the posterior tip of this scar to the anal notch being greater than the maximum length of this branch (unique to this species); relatively long epiplastral symphysis, its length being about half of that of the entoplastron (shared with Eo. lacombianus but not with Eo. farresi); intergular narrow, with subparallel margins throughout much of its path, and with the anterior border being much narrower than that of each gular (unique to this species); relatively short overlap of the latero-posterior region of the humeral scutes on the hyoplastra (shared with Eo. lacombianus but not with Eo. farresi); subrounded lateral margins of the posterior plastral lobe (unique to this species); relatively wide and short anal notch, its full length being approximately about half of its width (shared with Eo. lacombianus but not with Eo. farresi).

Description. The skull of MNHN.F CGR 101 is dorso-ventrally crushed (Figure 3). It lacks its posterior region. The length of the preserved region, measured on the axial plane, is about $11 \mathrm{~cm}$. Most of the lower jaw, except the distal part of its left branch, is also preserved. Due to its preservation, the beak point is pushed in the fossa premaxillaris and the jaw has not been isolated from the skull. Therefore, the characters corresponding to the dorsal region of the jaw, and those corresponding to the anterior and lateral palate areas, are not known. The preserved region of the skull is subtriangular in dorsal view. The contour shows a slightly shortened and protrudent snout, the lateral borders widening just at the orbits, creating a weak lateral concavity, and diverging up to the quadratojugal area. The dorsal roof is weakly elevated, with a small elevation at the fronto-parietal suture. This skull lacks a premaxillary beak. The nares are rectangular, and wider than long. The snout is short, its length being less than one third of the length of the orbits. It lacks nasal bones. The prefrontals are slightly longer than wide. Their medial length is less than that of the frontals. The interorbital space is relatively wide, its minimum width being greater than the maximum length of the orbits. It lacks an interorbital Podocnemis groove or any longitudinal depression. The sutures between the prefrontals and the frontals, and those between the frontals and the parietals, are subperpendicular to the axial plane. The frontals are in contact with the postorbitals latero-posteriorly, and with the parietals posteriorly. The prefrontals, frontals and postorbitals delimit the dorsal margin of the orbits. The orbits are dorso-laterally located and elliptical. The postorbitals are longer than wide, completely separating the jugals from the parietals. The jugals are in contact with the maxillae and the orbits anteriorly, the postorbitals dorsally, and the quadratojugals posteriorly. The maxillae define the lower margin of the orbits. The suborbital space is higher than the orbits. The skull lacks a cheek emargination, the jugal going down between the quadratojugal and the maxilla, creating a wide straight ventral lateral border. The premaxillae separate the maxillae, both in the anterior and in the palatal views. The pterygoids are medially in contact. The left proces- 

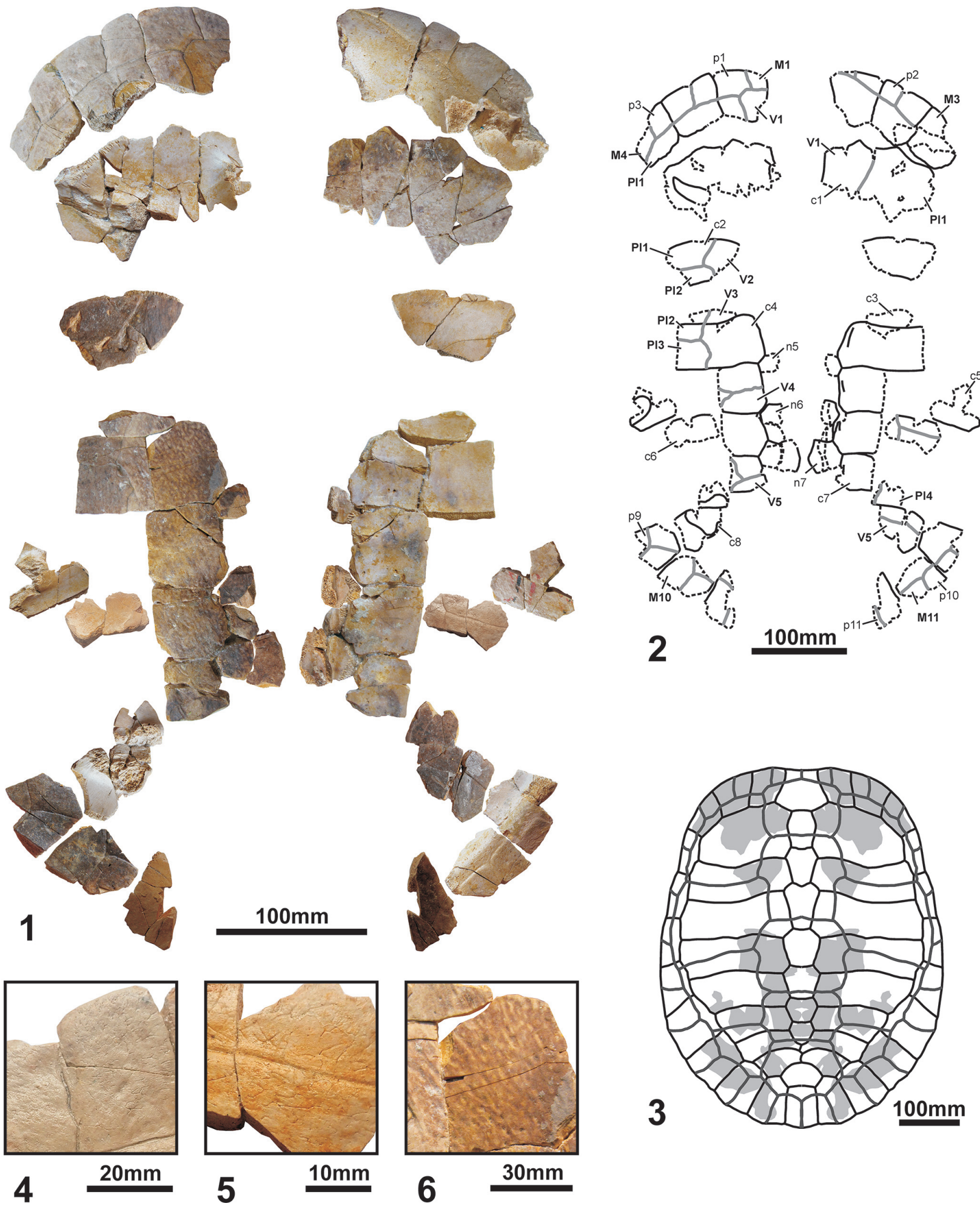

FIGURE 4. Some elements of the carapace of the holotype of Eocenochelus eremberti comb. nov., MNHN.F CGR 101, from the middle Eocene (Lutetian) of Saint-Germain-en-Laye (Yvelines, Île-de-France, France). 1-2, plates of the carapace, in dorsal and ventral views. 3-4, reconstruction of the dorsal view of the shell, showing the position of all these elements of the carapace. 4-6, details of the outer surface of some plates of the carapace: the second left peripheral (4), the distal region of the sixth right costal (5), and the proximal region of the fourth left costal (6). Abbreviations: c, costal; M, marginal scute; $n$, neural; $p$, peripheral; PL, pleural scute; py, pygal; $V$, vertebral scute. 
sus trochlearis pterygoidei is much externally eroded, and the right one is slightly incomplete. Its anterior face is not perpendicular to the axial plane, but posteriorly slightly directed. The basisphenoid is wider than long. It forms a short, obtuse wedge that penetrates between the rear regions of both pterygoids. The contact between the basisphenoid and the basioccipital is convex. A well-developed cavum pterygoidei is present, showing a large anterior opening. It was partly covered by the pterygoid wings, best preserved on the left side. Its wide dorsal opening in the sulcus cavernosus is visible on the right side. The condylus mandibularis quadrati seems neither particularly shortened nor relatively elongated in relation to its width.

The interparietal scute has a medial concavity on the anterior margin, with two short anterior arcs, forming a heart-shape. It does not contact the frontal bones. The frontal-parietal scutes boundary obliquely crosses the postorbital bones. The ventralmost region of the frontal scutes is located on the antero-dorsal area of the jugal bones. Probably the complete subocular scutes, but also the partial frontal, masseterian and maxillary scutes, overlap the jugals.

The lower jaw is very robust (Figure 3.3-3.6). Its labial margin, from the symphysis to the coronoid process, is nearly straight, the dorsally directed beak being therefore short. Due to the thickening of the dentary, its lateral surface lacks a concavity in ventral view. The mandibular symphysis, anteriorly ending in an acute angle, is long and constitutes about $40 \%$ of the total length of the lower jaw. Thus, it reaches the level of the foramen intermandibularis medius. The dorsal surface of the posterior region of the mandibular symphysis is not vertical, constituting a slope of about 45 degrees. The surangular is low laterodorsally and, below, the angular is long and laterally concave around the well-developed processus retroarticularis. In ventral view, the posteroventral foramen of the chorda tympani is visible, being fully enclosed in the jaw.

MNHN.F CGR 101 has a relatively large shell, the length of its plastron being of at least $60 \mathrm{~cm}$ (Figures 4-5) and, therefore, being relatively long for its estimated width (estimated maximum width about $38 \mathrm{~cm}$ ). The dorsal shell is decorated by the combination of several patterns: presence of millimetric short linear and dichotomic sulci; weakly undulated surface composed of small and very weak pits and granulations; presence of narrow and low rounded ridges, radially oriented from the vertebral and pleural centers of radiation (Figures
4.4-4.6). The outer surface of the plastron is decorated by sparce fine punctuations, weak pits and minute sulci (Figure 5). The carapace lacks a medial keel (Figure 4). It has at least seven neurals. At least the fifth and sixth neurals, partially preserved, are hexagonal in morphology, and long relative to their width. Their anterolateral-margins are shorter than the posterolateral. The anterior nuchal border is interpreted as not as elongated as that of the first pair of peripherals, considering the slightly rounded anterior border of these plates. The preserved three anterior and three posterior peripherals are relatively elongated, being approximately as long as wide. All of them are thinned in section toward the free border. The lip of the peripherals ninth and tenth, at the visceral boundary of the marginals, is not strongly developed. The axillary processes have a relatively long contact with the first pair of costals, anteriorly reaching the posterior margin of the second pair of peripherals. The inguinal processes contact the lateral region of the fifth costals. The iliac scars are located in the visceral region of both the seventh and the eighth costals. Posterior peripheral points are not present. The first vertebral is heptagonal, with short lateroanterior margins. It is wider than the nuchal plate. The overlap of the first pair of marginals on the nuchal is shorter than half of the length of the lateral side of this plate, but the second to fourth marginals are long, overlapping more than half of the length of the peripherals. Viscerally, the first marginal scute is very short, especially toward the medial region. However, the posterior marginals are long.

The posterior plastral lobe is narrower than the anterior (Figure 5). The anterior is trapezoid, with its lateral borders being anteriorly converging, its length being half of its width. It lacks gular protrusions. The epiplastral symphysis is relatively long, its length being about half of that of the entoplastron. The entoplastron is rhomboidal. The mesoplastra are subrounded, longer than wide. The lateral margins of the posterior plastral lobe are subrounded. The anal notch is relatively shallow, its length being about half of its width. Its lateral margins are also subrounded. The gular scutes are anteriorly wider and longer than the intergular. They meet medially. The intergular reaches the anterior entoplastron margin. It is narrow, with subparallel margins throughout much of its path. The posterior margins of the humerals are located on the anterior half of the entoplastron and on the epiplastra, except in the lateral region, where the humerals slightly overlap the hyoplastra. 

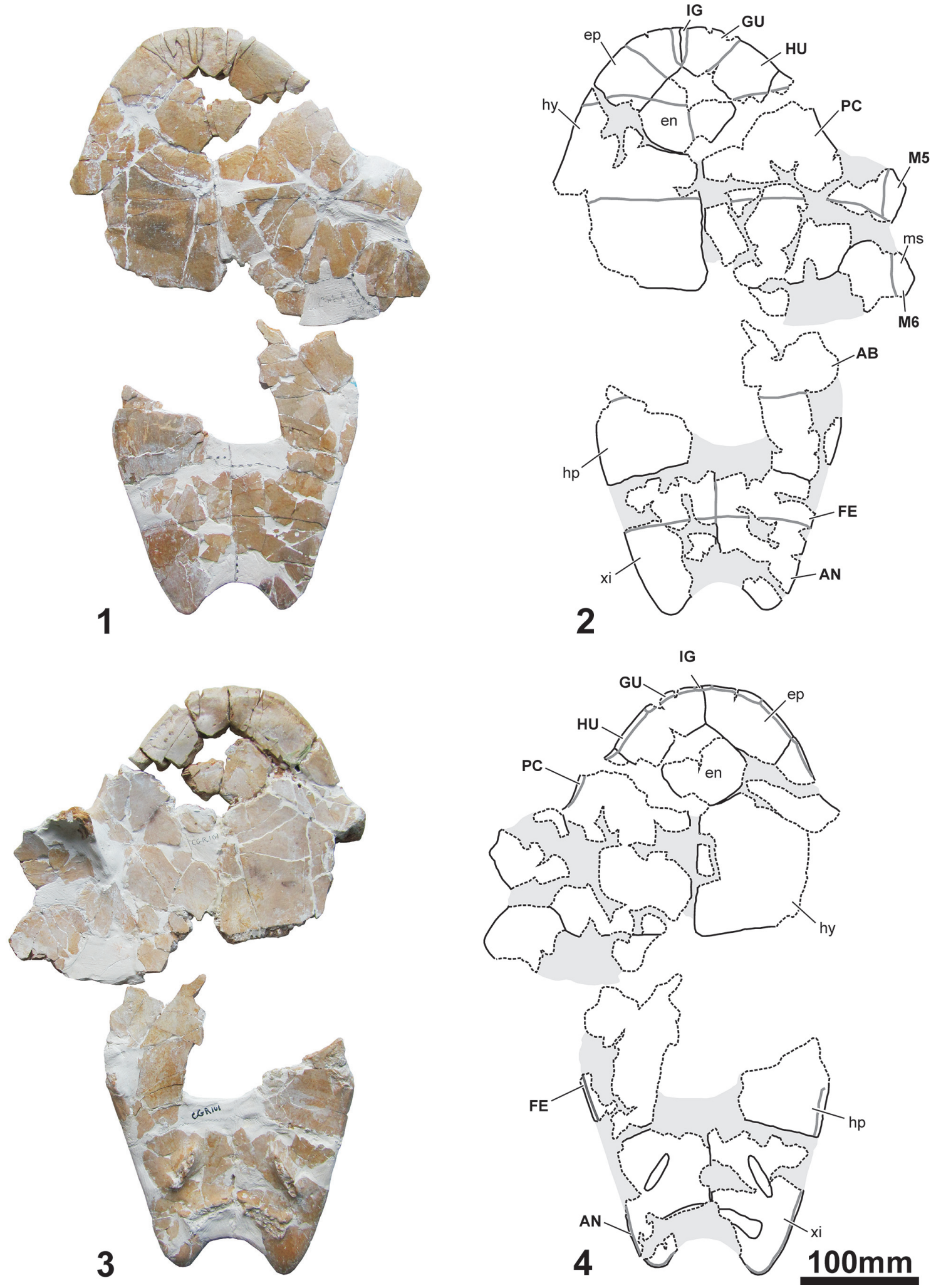

FIGURE 5. Plastron of the holotype of Eocenochelus eremberti comb. nov., MNHN.F CGR 101, from the middle Eocene (Lutetian) of Saint-Germain-en-Laye (Yvelines, Île-de-France, France), in ventral (1-2) and dorsal (3-4) views. Abbreviations: AB, abdominal scute; AN, anal scute; en, entoplastron; ep, epiplastron; FE, femoral scute; GU, gular scute; hp, hypoplastron; HU, humeral scute; hy, hyoplastron; IG, intergular scute; M, marginal scute; ms, mesoplastron; PC, pectoral scute; xi, xiphiplastron. 
The pectoral scutes do not contact the mesoplastra. A relatively long distance separates the anal scutes from the hypoplastra. Thus, the anal scutes overlap on the lateral border of the xiphiplastra is longer than that of the femorals, although less than twice as long (anal margins about $30 \%$ longer than those of the femorals). The dorsal expansion of the plastral scute borders is very short. The oblique transversal pubic scar is relatively long and narrow, being almost five times longer than wide. The ischatic scar is slightly longer laterally than medially. It is not close to either the anal notch margin or the xiphiplastral point.

The preserved fragmentary postcranial bones are robust, compared with those of other members of Pleurodira, including Erymnochelys madagascariensis (see Gaffney et al., 2011; Lapparent de Broin and Murelaga 1999; Lapparent de Broin et al., 2004; Reinach, 1903; Tronc and Vuillemin, 1973) (Figure 6.1-6.49). They show the general pattern present in freshwater podocnemidid turtles such as Er. madagascariensis. The humerus has a wide open angle of $115^{\circ}$ between the trochanters (Figure 6.38-6.43). As in Er. madagascariensis and in all the freshwater turtles, but also as in Bairdemys healeyorum, the femur is longer than the humerus, its shaft being relatively longer and robust (Figure 6.44-6.49). The scapula has a wide angle of about $90^{\circ}$ with the acromion (Figure 6.56.14), approximately as in $B$. healeyorum. The acetabular part is wide for its height: the height of the scapula and its acromion is relatively short at their fusion, and on the right scapulo-acromion remain, the width at the level of the corresponding coracoid sutural border is $68 \%$ of the height (Figure 6.156.19). The pelvis is short, being composed by relatively massive elements (Figure 6.20-6.37). The iliac body is wide and not medially narrowed, short for its height between the suture with the pubis and the proximal widening for the eroded costal scar part (Figure 6.26-6.31). The pubis is relatively low, its width being $103 \%$ of its height at the medial acetabular border (Figure 6.32-6.37). The ischium is also low and, mediolaterally, its shaft is slightly narrowed, being rounded below the proximal extremity (Figure 6.20-6.35). The preserved ventral suture with the xiphiplastron is anteromedially short, according to the scar on the plastron (Figure 5.36.4).

\section{Eocenochelus lacombianus sp. nov.} Figures 6.50-6.57, 7

zoobank.org/AB1F3F7C-E722-479D-AE9D-195192927714

Holotype. MNHN.F EBA 534 (Figure 7), a partial shell preserving the relatively complete dorsal car- apace (MNHN.F EBA 534.1), the nearly complete plastron (MNHN.F EBA 534.2); and fragmentary remains of both hemipelves (MNHN.F EBA 534.3 and MNHN.F EBA 534.4) (Figure 6.50-6.57).

Etymology. The specific name is in honor of Laurent Lacombe (Ouveilhan, France), who discovered the holotype and donated it to F. de Lapparent de Broin, who deposited it in the MNHN.

Type locality and horizon. Soulane (from the name of an occasional brook), Jonquières, Aude, Languedoc-Roussillon-Midi-Pyrénées, France (Figure 2) (Vigneaux, 1975). Grey-blueish marls with abundant remains of the gastropods Batillaria spp., upper part of the Upper sandstone-marly ormation, early Ypresian (from the upper part of the Ilerdian, at contact with the Ypresian continental molasse, toward the middle part of the lower Cuisian), early Eocene (Plaziat, 1984a, 1984b; Ellenberger et al., 1987).

Diagnosis. Member of Eocenochelus with seven neurals, lacking medial contact of the sixth pair of costals (differing from Eocenochelus farresi but sharing with Eocenochelus eremberti the presence of at least seven neurals); wide pubic scar, its width being approximately half of its length (not shared with Eo. eremberti and not known in Eo. farresi); presence of a well-developed posterior branch of the ischiatic scar reaching the short dorsal anal scute on the anal notch border, the distance from its posterior tip to the anal notch being about one third of the maximum length of this branch (not shared with Eo. eremberti and Eo. farresi, and not reaching the xiphiplastral point as in Eo. farresi); relatively long epiplastral symphysis, its length being about half of that of the entoplastron (shared with Eo. eremberti but not with Eo. farresi); intergular triangular, with well-developed posteriorly convergent lateral margins, and the anterior border being almost as wide as that of each gular (shared with Eo. farresi but not with Eo. eremberti); relatively short overlap of the latero-posterior region of the humeral scutes on the hyoplastra (shared with Eo. eremberti but not with Eo. farresi); notably narrow posterior plastral lobe (shared with Eo. farresi but not with Eo. eremberti) but with a slightly concave border (unique to this species); relatively wide and short anal notch with straight borders, its length being about half of its width (not shared with Eo. farresi).

Description. MNHN.F EBA 534 has a relatively small shell size. The carapace is relatively wide for its length (maximum length interpreted as close to $29.5 \mathrm{~cm}$, and maximum width of about $25 \mathrm{~cm}$, these dimensions being affected by a postmortem 

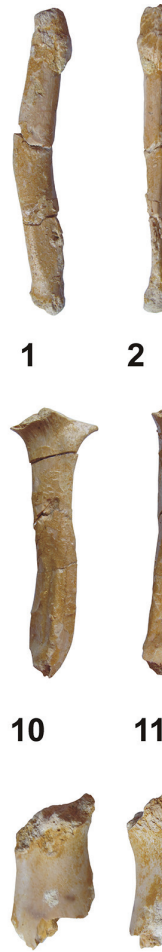

26

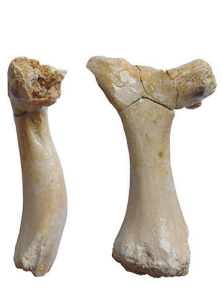

38

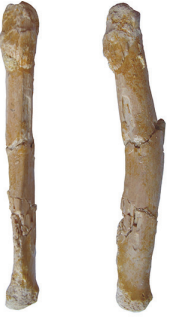

2

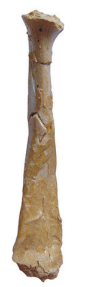

11

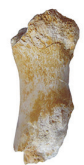

39

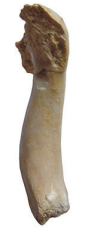

3

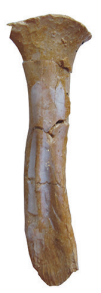

12

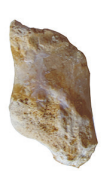

28

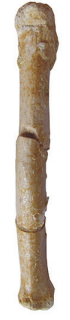

4

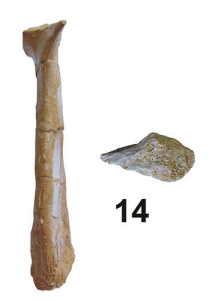

13

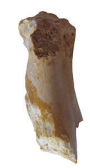

29

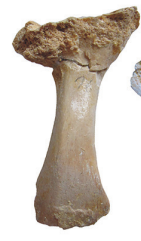

41

\section{3}

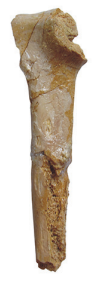

5

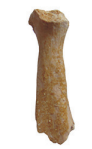

15

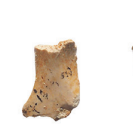

20

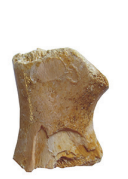

32

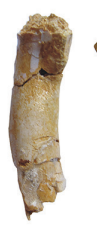

$44 \quad 45$

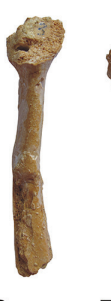

6

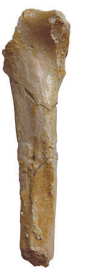

7

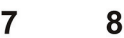

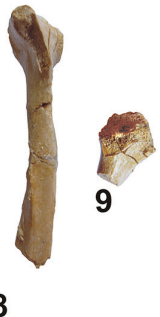

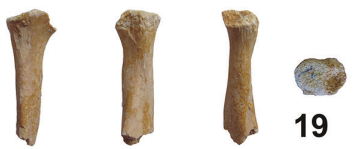

$\begin{array}{lll}16 & 17 & 18\end{array}$

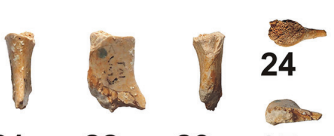

$21 \quad 22 \quad 23 \quad 25$

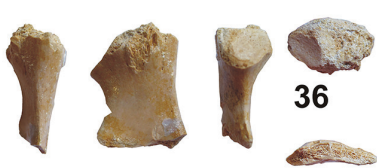

$\begin{array}{llll}33 & 34 & 35 & 37\end{array}$

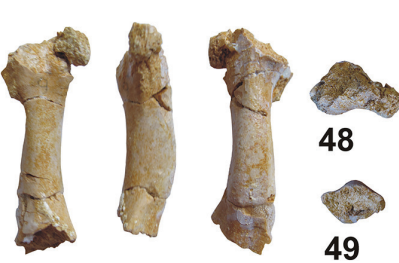

49

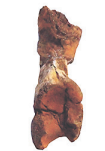

50

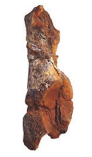

51

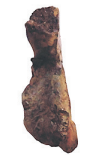

52

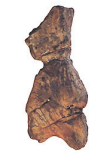

53

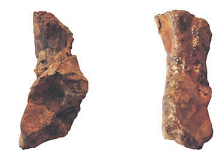

55

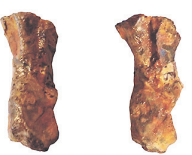

$56 \quad 57$

FIGURE 6. Fragmentary skeletal bones of the holotypes of Eocenochelus eremberti comb. nov., MNHN.F CGR 101, from the middle Eocene (Lutetian) of Saint-Germain-en-Laye (Yvelines, Île-de-France, France) (1-49), and Eocenochelus lacombianus sp. nov., MNHN.F EBA 534, from the lower Eocene (Ypresian) of Soulane (Jonquières, Aude, France) (50-57). 1-4, left hyoid horn, second branchial horn, in dorsal (1), medial (2), ventral (3) and lateral (4) views. $5-9$, acromion of the right scapula with the partial glenoid articular region, in posterior (5), ventral (6), anterior (7) and dorsal (8) views, and articular part in ventrolateral view (9). 10-14, acromion of the left scapula with the partial glenoid articular region, in posterior (10), ventral (11), anterior (12) and dorsal (13) views, and proximal articular section (14). 15-19, left coracoid in dorsal (15), posteroventral (16), ventral (17) and anterior (18) views, and articular-glenoid facet part, in proximal view (19). 20-25, left ischium, in anterior (20), medial (21), posterior (22) and distal (23) views, and dorsal (24) and ventral (25) sections. 26-31, right ilium, in posterior (26), lateral (27), anterior (28) and medial (29) views, and dorsal (30) and ventral (31) sections. 32-37, left pubis, in anterior (32), medial (33), posterior (34) and lateral (35) views, proximal articular-acetabular region in dorsal view (36), and ventral section (37). 38-43, left humerus, in anterior (38), ventral (39), posterior (40) and dorsal (41) views, and proximal (42) and distal (43) sections. 44-49, right femur, in anterolateral (44), ventral (45), posteromedial (46) and dorsal (47) views, and proximal (48) and distal (49) sections. 50-53, right hemipelvis, in lateral (50), posterior (51), anterior (52) and medioventral (53) views. 54-57, left hemipelvis, in lateral (54), posterior (55), anterior (56) and medial (57) views. 
moderate flattening). The maximum length of its plastron is $29.3 \mathrm{~cm}$ (Figure 7). It lacks a medial keel on the carapace (Figure 7.1-7.5). There are seven neurals. The second to sixth neurals are hexagonal, almost as wide as long, their lateroanterior margins being shorter than the latero-posterior ones. The seventh neural is pentagonal and as wide as long. Both the seventh and eighth costals are in contact medially. Posterior peripheral points are not present. The axillary processes have a relatively long contact with the first pair of costals, anteriorly reaching the posterior margin of the second pair of peripherals. The inguinal processes slightly contact in a forward direction the lateral region of the fifth costals in a rounded area, and rearwardly they reach to the antero-medial area of the eighth peripherals. The iliac scars are located on the visceral region of both the seventh and the eighth costals. The first vertebral scute is wider than the nuchal plate. The second to fourth vertebrals are hexagonal; the posterior margin of the fourth is significantly shorter than the anterior one and the latero-anterior margins are shorter than the latero-posterior margins. The width of the second to fourth vertebrals is similar. The fifth vertebral is probably heptagonal, being posteriorly wide. The first pair of marginals overlaps less than half of the nuchal. Viscerally, the marginal scutes are very short, except for the posterior ones, which are relatively long and overlap a markedly and thick bordering lip.

The length of the plastron of MNHN.F EBA 534 is close to $30 \mathrm{~cm}$ and its bones are thin. The posterior plastral lobe is narrower than the anterior (Figure 7.6-7.9). The anterior is subrounded, its length being greater than half of its width. It lacks well-developed gular protrusions, but the intergular anterior border is rounded. The epiplastral symphysis is long, its length being about half of that of the rhomboidal entoplastron. The hyoplastra are longer than the hypoplastra. The lateral margins of the posterior plastral lobe are strongly convergent posteriorly and slightly concave. Because of the basal narrowness, the inguinal notches are relatively wide and a relatively shallow anal notch is present. Its length is about half of its width. The lateral margins are nearly straight. The gulars are in contact along the midline, posteriorly to the shorter intergular scute. Anteriorly, they are barely wider than the intergular. The intergular overlaps the most anterior region of the entoplastron. The lateral margins of this scute are strongly convergent posteriorly. Only the most lateral region of each humeral scute barely overlaps the anteriormost tips of the hyo- plastra. The gular scutes are medially shorter than the humerals. The pectoral scutes do not contact the mesoplastra. The distance of the abdominal scutes to the entoplastron is almost equal to the length of this plate. The anterior half of the femoral scutes overlaps the hypoplastra, and this overlap is longer than that of the abdominals. The anterior margin of the anal scutes is located far behind the hypoplastra. Thus, on the xiphiplastra, the anal lateral borders are slightly longer than those of the femorals, the lateral margins of the anals being $24 \%$ longer than those of the femorals. The dorsal expansion of the plastral scute borders is poorlydeveloped. The pubic scars are relatively wide, their width being approximately half of their length. A well-developed posterior branch of each ischiatic scar is present, its posterior tip being close to the anal notch border inside the xiphiplastral point.

The fragmentary ilia are preserved, with the pubic acetabular part of the left side, and the pubic and ischiatic acetabular parts of the right side (Figure 6.50-6.57). The acetabular pubic part is elongated relative to the whole acetabulum width. The iliac shaft is slightly narrrower for its height than in Er. madagascariensis and in Eo. eremberti.

\section{Eocenochelus farresi sp. nov. Figure 8}

\section{zoobank.org/14C22DFF-85B1-46AF-96BB-BC2AED850248}

Holotype. MGSB 74.641-GLV.T.45, Farrés collection, deposit in Geolab-Vic (GLV) by delegation of the MGSB. An articulated shell preserving an almost complete plastron and a partial carapace (Figure 8).

Etymology. The specific name is in honor of the geologist Francesc Farrés (GLV, Catalonia, Spain), who discovered and prepared the holotype.

Type locality and horizon. Can Beuloví, Sobremunt, Osona, Barcelona, Catalonia, Spain (Figure 2). Sant Martí Xic Formation, Priabonian, late Eocene (Sanjuan et al., 2012).

Diagnosis. Member of Eocenochelus with six neurals, resulting in a medial contact between the sixth, seventh and eighth pairs of costals (unique to this species); a well-developed posterior branch of the ischiatic scar present, reaching the short dorsal anal border at the xiphiplastral point (unique to this species); very short epiplastral symphysis, less than one-fifth the length if the entoplastron (unique to this species); intergular triangular, with welldeveloped, posteriorly convergent lateral margins and an anterior border almost as wide as that of each gular (shared with Eocenochelus lacombianus but not with Eocenochelus eremberti); long lateral overlap of the humeral scutes onto hyoplas- 


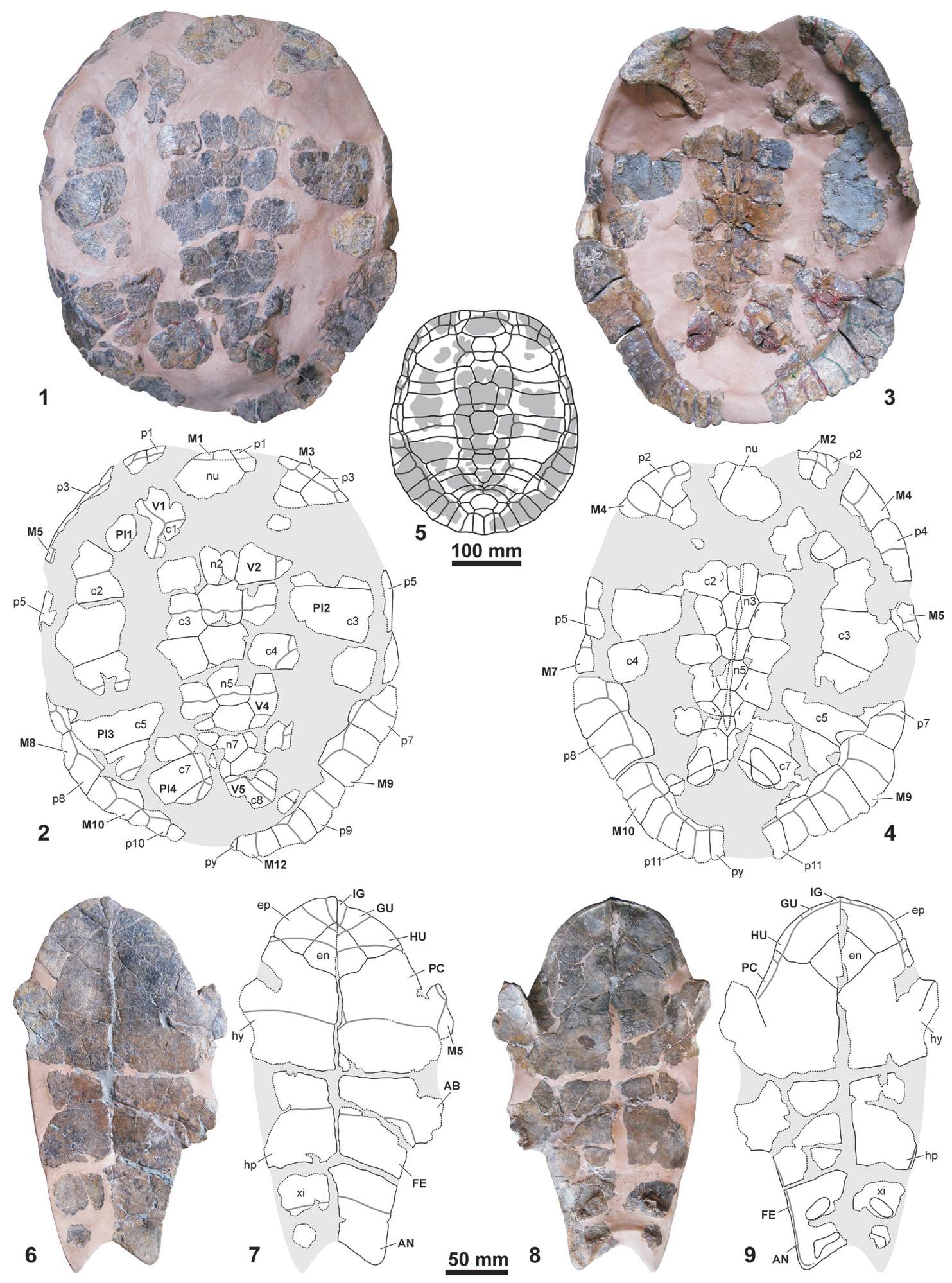

FIGURE 7. Shell of the holotype of Eocenochelus lacombianus sp. nov., MNHN.F EBA 534, from the lower Eocene (Ypresian) of Soulane (Jonquières, Aude, France). 1-2, carapace, in dorsal view. 3-4, carapace, in ventral view. 5, reconstruction of the dorsal view of the shell, showing the position of the preserved elements of the carapace. 6-7, plastron, in ventral view. 8-9, plastron, in dorsal view. Abbreviations: AB, abdominal scute; AN, anal scute; c, costal; en, entoplastron; ep, epiplastron; FE, femoral scute; GU, gular scute; hp, hypoplastron; HU, humeral scute; hy, hyoplastron; IG, intergular scute; M, marginal scute; ms, mesoplastron; $n$, neural; nu, nuchal; $p$, peripheral; PC, pectoral scute; PL, pleural scute; py, pygal; V, vertebral scute; xi, xiphiplastron. 

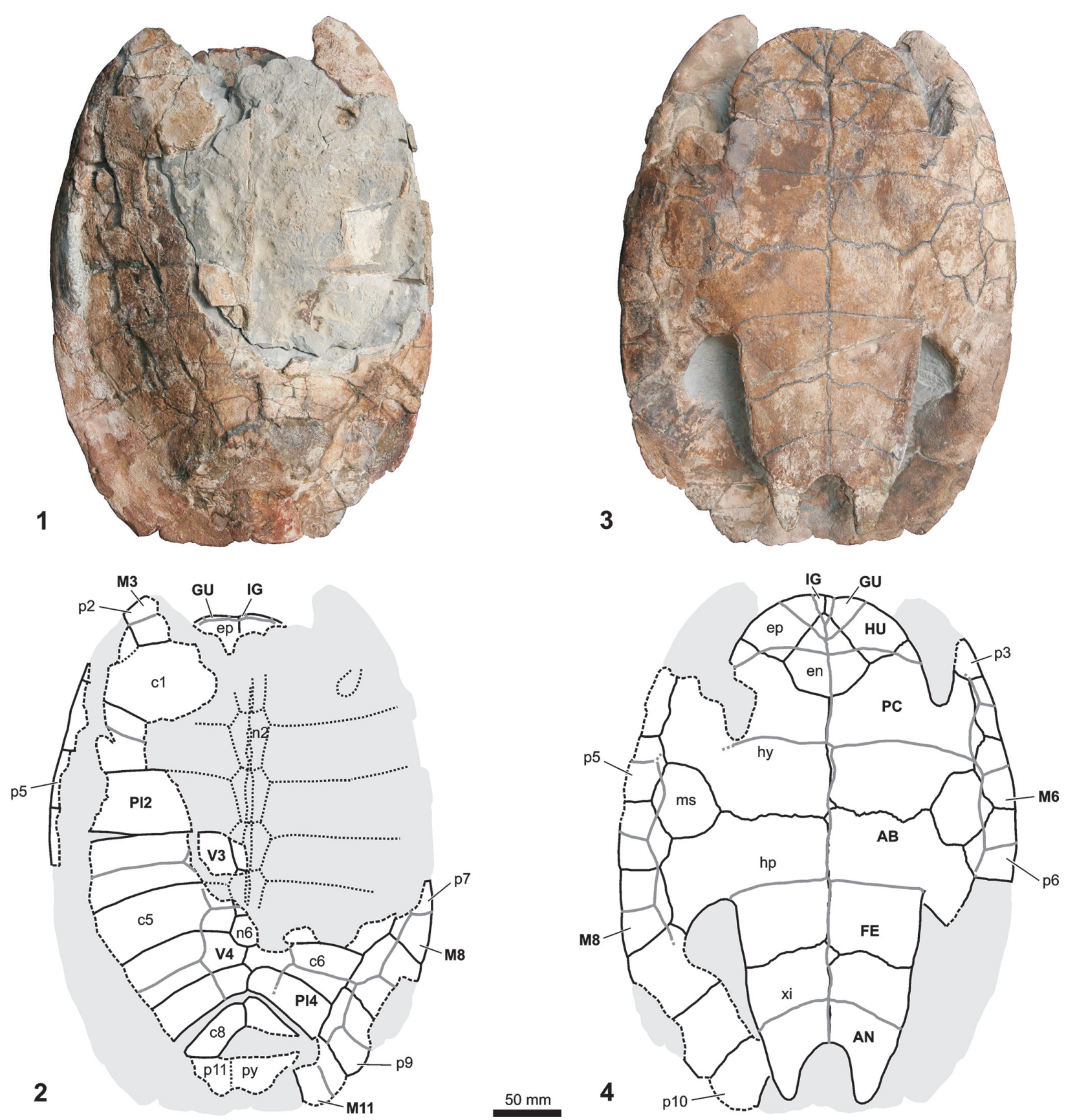

FIGURE 8. Shell of the holotype of Eocenochelus farresi sp. nov., MGSB 74.641-GLV.T.45, from the upper Eocene (Priabonian) of Can Beuloví (Sobremunt, Barcelona, Spain), in dorsal (1-2) and ventral (3-4) views. Abbreviations: $A B$, abdominal scute; AN, anal scute; c, costal; en, entoplastron; ep, epiplastron; FE, femoral scute; GU, gular scute; hp, hypoplastron; HU, humeral scute; hy, hyoplastron; IG, intergular scute; M, marginal scute; ms, mesoplastron; n, neural; $p$, peripheral; PC, pectoral scute; PL, pleural scute; py, pygal; V, vertebral scute; xi, xiphiplastron.

tra, the humero-pectoral sulci contacting the middle region of the epiplastral-hyoplastral sutures (unique to this species); slightly convex lateral margins of the posterior plastral lobe (convexity much less developed than in Eo. eremberti, but not convave as in Eo. lacombianus); deep U-shaped anal notch, being almost as long as wide (unique to this species).

Description. The shell of MGSB 74.641-GLV.T.45 is moderately large and moderately long for its width (the maximum length of the preserved region is about $43 \mathrm{~cm}$, and the maximum width is about 
$30.5 \mathrm{~cm}$ ); it was moderately flattened post-mortem. This taxon lacks a medial keel on the carapace (Figure 8.1-8.2). It has six neurals, relatively long for their width. The second to fifth neural elements are hexagonal and longer than wide. Their lateroanterior margins are shorter than their latero-posterior margins. The sixth neural is pentagonal. The plates of the last three pairs of costals are in contact medially. Posterior peripheral points are not present. The third and fourth vertebral scutes are hexagonal. The third one is slightly wider than the fourth. Ventrally, the sixth pair of marginals overlaps the lateral region of the mesoplastra.

The length of the plastron of MGSB 74.641GLV.T.45 is about $38 \mathrm{~cm}$. The posterior plastral lobe is narrower than the anterior (Figure 8.3-8.4). The anterior lobe is subrounded, lacking gular protrusions and with boadly diverging posterolateral borders that create relatively narrow axillary notches. Its length is equal to half of its width. The epiplastral symphysis is very short, less than onefifth the length of the entoplastron. The entoplastron is rhomboidal, its latero-anterior margins being longer and straighter than the latero-posterior ones. Along the midline, the hypoplastra are slightly longer than the hyoplastra. The mesoplastra are subrounded, being longer than wide. The lateral margins of the posterior plastral lobe are slightly convex. The anal notch is deep, being almost as long as wide, and U-shaped with subrounded lateral margins. The xiphiplastral extremities are dorsally thickened, widely and longly covered by the ischiatic scar up to the short dorsal border of the anal scute, at the end of the point. The gular scutes are longer than the intergular, with wider anterior margins. Posteriorly, the triangular intergular slightly overlaps the anterior region of the entoplastron. The gulars are medially in contact and medially are as long as the humerals. This specimen shows a large overlap of the latero-posterior region of the humerals onto the hyoplastra. The distance from the pectoro-abdominal sulci to the posterior margin of entoplastron is less than the length of this plate. The femorals overlap onto the hypoplastra, on a scale similar to that of the abdominals. The femoro-anal sulci are located approximately over half of the xiphiplastra length, the anal lateral borders on the xiphiplastra being about $30 \%$ longer than the femoral borders. The dorsal expansion of the plastral scute borders is very short.

\section{DISCUSSION}

Eocenochelus nov. gen. is recognized as a podocnemidid based on the presence of a cavum pterygoidei partly covered by the pterygoid wings. It is identified as a member of the Erymnochelyinae based on the large anterior opening of the cavum pterygoidei with a wide dorsal opening in the sulcus cavernosus (Lapparent de Broin, 2000a; Pérez-García and Lapparent de Broin, 2015).

The only erymnochelyine genus so far defined in the Eocene of Europe is Neochelys. This endemic European genus is represented by 10 species, distributed from the early Ypresian to the late Bartonian (Pérez-García and Lapparent de Broin, 2015; Cadena, 2015a). Neochelys differs from Eocenochelus in several cranial and shell features (Table 1): a prominent snout with lateral subparallel edges, in contrast to the much shorter snout of Eocenochelus with oblique borders; subrounded orbits, higher than the suborbital space, being elliptical and lower than that space in Eocenochelus; orbits located more laterally than in Eocenochelus; interorbital space approximately as wide as the orbit length, which is narrower than that of Eocenochelus; presence of a cheek emargination; anterior interparietal scute region overlapping the frontals but not contacting them as in Eocenochelus; shorter mandibular symphysis in relation to the length of the jaw, being more slender and anteriorly rounded; posterior peripheral points; subequal width of the plastral lobes; subtrapezoidal anterior lobe with angular to rounded antero-lateral edges and slightly widened posterior lobe; pectoral postero-lateral margins in contact with the anterior edge of the mesoplastra (see Figure 9).

In addition to all of the characters so far discussed, Eocenochelus clearly differs from Neochelys in that it lacks the relatively long intergular scute present in Neochelys (a condition present in most pleurodires, including the oldest representatives), which is longer than the gulars or sometimes as long as them and which prevents a medial contact of these scutes. The presence of gulars in contact at the midline, posteriorly to a relatively short intergular, is diagnostic of the Erymnochelys group, allowing the attribution of Eocenochelus to this lineage (Broin, 1988; Lapparent de Broin, 2000a; Pérez-García and Lapparent de Broin, 2015). However, Eocenochelus shows several skull autapomorphies, and also exclusive unique combinations of characters both in the cranial skeleton and in the shell, which confirm that it is a new genus (Lapparent de Broin in Merle, 2008; Pérez-García and Lapparent de Broin, 2015). The recognition of this 
TABLE 1. Comparison of some cranial and postcranial characters of three podocnemidids: the new European Eocene genus Eocenochelus (represented by the three species studied here, Eocenochelus lacombianus sp. nov., Eocenochelus eremberti comb. nov. and Eocenochelus farresi sp. nov.), the Malagasy Erymnochelys (represented by the extant species Erymnochelys madagascariensis) and the European Eocene Neochelys (represented by ten species). For more information and detailed comparisons see the text.

\begin{tabular}{|c|c|c|c|}
\hline & Eocenochelus & Erymnochelys & Neochelys \\
\hline Snout & Short & Prominent & Prominent \\
\hline Premaxillary beak & Absent & Present & Absent \\
\hline Suborbital space height & $\begin{array}{l}\text { Greater than the orbits } \\
\text { height }\end{array}$ & Less than the orbits height & Less than the orbits height \\
\hline Interorbital space & Wider than the orbits length & $\begin{array}{l}\text { Narrower or as narrow as the } \\
\text { orbits length }\end{array}$ & $\begin{array}{l}\text { Narrower or as narrow as the } \\
\text { orbits length }\end{array}$ \\
\hline Cheek emargination & $\begin{array}{l}\text { Absent. Filled by a ventral } \\
\text { expansion of the jugal }\end{array}$ & $\begin{array}{l}\text { Small. In large part filled by the } \\
\text { jugal or jugal and quadratojugal } \\
\text { ventral expansion }\end{array}$ & $\begin{array}{l}\text { Largely present between the } \\
\text { maxilla and the quadratojugal }\end{array}$ \\
\hline $\begin{array}{l}\text { Interparietal scute anterior } \\
\text { extension }\end{array}$ & Not contacting the frontals & Overlapping the frontals & Overlapping the frontals \\
\hline $\begin{array}{l}\text { Interparietal anterior } \\
\text { concavity }\end{array}$ & Present & Absent & Present \\
\hline $\begin{array}{l}\text { Mandibular symphysis } \\
\text { length }\end{array}$ & $\begin{array}{l}\text { About } 40 \% \text { of the lower jaw } \\
\text { length }\end{array}$ & $\begin{array}{l}\text { About } 30 \% \text { of the lower jaw } \\
\text { length }\end{array}$ & $\begin{array}{l}\text { About } 25 \% \text { of the lower jaw } \\
\text { length }\end{array}$ \\
\hline Lower jaw & Very robust & Relatively robust & Slender \\
\hline Number of neurals & 6 to 7 & 6 & 6 to 7 \\
\hline Plastral lobes & $\begin{array}{l}\text { Posterior lobe narrower } \\
\text { than the anterior }\end{array}$ & $\begin{array}{l}\text { Posterior lobe narrower than the } \\
\text { anterior }\end{array}$ & Subequal width of both lobes \\
\hline Anterior lobe morphology & Subrounded & Subrounded to subtrapezoidal & Subrounded to subtrapezoidal \\
\hline Intergular length & $\begin{array}{l}\text { Long, reaching or overlying } \\
\text { the entoplastron }\end{array}$ & $\begin{array}{l}\text { Short, not reaching the } \\
\text { entoplastron }\end{array}$ & $\begin{array}{l}\text { Long, reaching or overlying the } \\
\text { entoplastron }\end{array}$ \\
\hline $\begin{array}{l}\text { Medial contact of the } \\
\text { gulars }\end{array}$ & $\begin{array}{l}\text { Present. Intergular not } \\
\text { contacting the humerals }\end{array}$ & $\begin{array}{l}\text { Present. Intergular not } \\
\text { contacting the humerals }\end{array}$ & $\begin{array}{l}\text { Absent. Intergular contacting the } \\
\text { humerals, and contacting or not } \\
\text { the pectorals }\end{array}$ \\
\hline
\end{tabular}

exclusive combination of shell characters allows taxa only known from the shell to be recognized as members of the Erymnochelys group from the Eocene of Western Europe and also to be attributed to this genus (i.e., the new Eocenochelus lacombianus and Eocenochelus farresi).

The upper Miocene-Pliocene Turkanemys pattersoni and the extant Erymnochelys madagascariensis have a skull beak, but this structure is not present in all representatives of the Erymnochelys group. For example, the lower Oligocene 'Podocnemis' fajumensis and the new Eocenochelus eremberti (the only species of the genus in which the skull is known) lack this structure, simply having a posteriorly downward protruding maxillae (as also in Dacquemys paleomorpha). In Eocenochelus, the nares are wider than long, as in 'Podocnemis' fajumensis and Er. madagascariensis (and as in D. paleomorpha and Mogharemys blanckenhorni), but not as in T. pattersoni. The snout of Eocenochelus is shorter than that of T. pattersoni and, especially, of 'P.' fajumensis and Er. madagascariensis (and $D$. paleomorpha). The prefrontals are shorter that the frontals, as in ' $P$.' fajumensis, but not in T. pattersoni and Er. madagascariensis (and D. paleomorpha). The presence of an interorbital longitudinal depression, developed in some ' $P$.' fajumensis specimens, is absent in the other members of the Erymnochelys group. 'Podocnemis' fajumensis differs from the other representatives of the Erymnochelys group due to the presence of a medial anteriorly directed prominence of the prefrontal-frontal contact, this suture being transverse to slightly sinuous in the other taxa. The presence in Eocenochelus of an interorbital space whose minimum width is greater than the maximum length of the orbits is not shared with any other unambiguous member of the Erymnochelys group (it is wider in $D$. paleomorpha and $M$. blanckenhorni). Eocenochelus has a high suborbital space, slightly higher than that of Er. Madagascariensis, but significantly higher than those of ' $P$.' 

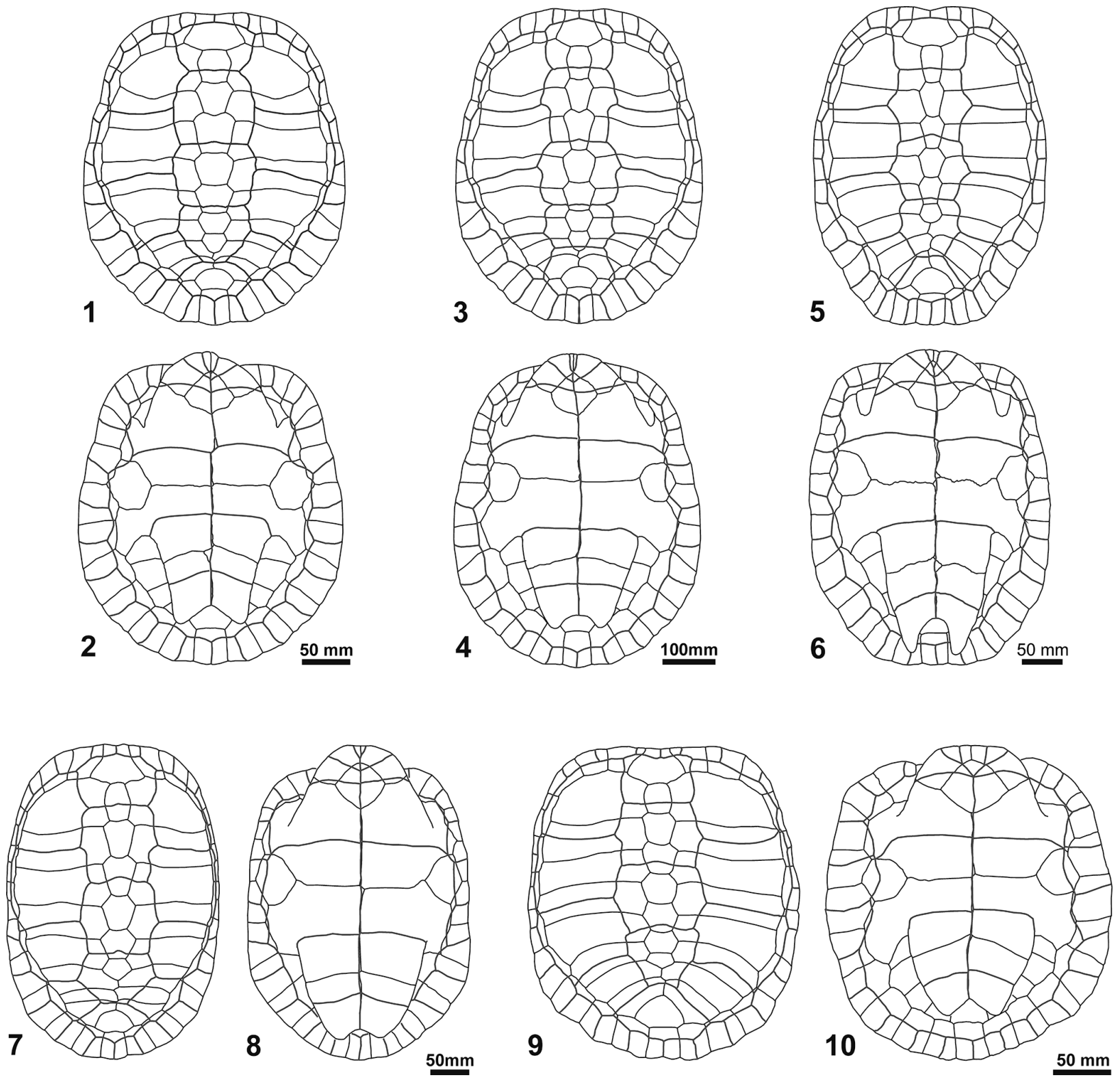

FIGURE 9. Reconstruction of the dorsal and ventral views of the shells of the three Podocnemididae species studied here, Eocenochelus lacombianus sp. nov. (1-2), Eocenochelus eremberti comb. nov. (3-4), and Eocenochelus farresi sp. nov. (5-6), compared to those of the extant Malagasy Erymnochelys madagascariensis (7-8), and the European Eocene Neochelys liriae (9-10).

fajumensis, T. pattersoni (and also than those of $D$. paleomorpha and M. blanckenhorni), in which the orbits are higher than the suborbital space.

Eocenochelus is the only representative of the Erymnochelys group that lacks a cheek emargination, the latero-ventral margin of the skull being straight. The cheek emargination is low in Erymnochelys madagascariensis, in which it has also been secondarily filled, but incompletely so, by one of two possible ways (Lapparent de Broin and Werner, 1998, figure 6), either exclusively by the jugal as in Eocenochelus or by both the jugal and the quadratojugal. This filling, eventually representing a shared tendency with Eocenochelus (only known for Eocenochelus eremberti), could be possibly due to the development of a powerful pointed acute beak; but if so it is puzzling that it is not present in Turkanemys pattersoni, also possessing a dentary beak although perhaps less acute (the lower jaw has not been appropriately represented). A cheek filling by various ways also is present in some bothremydids with a strong masticatory pal- 
ate (Lapparent de Broin and Werner, 1998; Gaffney et al., 2006). The complete filling may be due to a wider and higher beak in Eocenochelus than in Er. madagascariensis, but it is not present in Turkanemys pattersoni, a taxon that has also a dentary beak. Turtles such as cheloniids, sandownids and bothremydids, with a powerfull masticatory apparatus and large triturating surfaces, reinforce the skull box by the filling of the lateral cheek emargination (Lapparent de Broin and Werner, 1998; Tong and Meylan, 2013; Cadena, 2015b). The emargination is relatively high in 'Podocnemis' fajumensis and T. pattersoni, reaching a height greater than the ventral margin of the orbit. The presence of a medial concavity on the anterior margin of the interparietal scute of Eocenochelus (known for Eo. eremberti) is unique to this member of the Erymnochelys group. Furthermore, the absence of any overlap of this scute on the frontals is not shared with any other representative.

The lower jaw of Eocenochelus shows numerous differences when compared with the lower jaws of other members of the Erymnochelys group in which a lower jaw has been described (i.e., Turkanemys pattersoni and Erymnochelys madagascariensis) and also with a lower jaw from the Maastrichtian of the Berivotra region (Madagascar), which was attributed to cf. Erymnochelys (see Gaffney and Forster, 2003), but is considered here as aff. Erymnochelys sp. These differences are related mostly to the great thickness of the lower jaw in Eocenochelus. Thus, it lacks a well-developed concavity on the occlusal surface, from the coronoid process to the antero-dorsal region of the symphysis, the margin being nearly straight up to the pointed beak (hidden in the fossa premaxillaris), and lacking a lateral dentary concavity, the surangular being lowered and, below it, the angular being higher laterally. However, the condylus mandibularis of the lower jaw is greatly protrudent in relation to the processus retroaticularis, which is relatively long as in the Upper Cretaceous specimen of aff. Erymnochelys sp. from Madagascar. The mandibular symphysis of Eocenochelus is much longer in relation to the total length of the lower jaw than in the other members of the Erymnochelys group, being the only taxon in which the mandibular symphysis posterior margin reaches the level of the foramen intermandibularis medius. In addition, the dorsal surface of the mandibular symphysis, located behind the occlusal surface, becomes nearly vertical in the posterior region of all these taxa except in the case of Eocenochelus, where it constitutes a slope of about 45 degrees.
Eocenochelus lacks the medial keel present in the carapace of Kenyemys williamsi and in some unpublished specimens of Turkanemys pattersoni belonging to the NMK collection. The presence of very short distal margins on the seventh costals of T. pattersoni, more than two times shorter than those of the eighth ones, is not shared with Eocenochelus. The first vertebral being wider than the nuchal is unlike the condition in Kenyemys williamsi. In fact, the morphology of the first vertebral of $K$. williamsi (i.e., not heptagonal with short latero-anterior margins, but instead pentagonal as in 'Stereogenys' libyca) is a derived feature unique to that taxon, in which the first pair of marginals overlap as much as half of the length of the latero-anterior nuchal margins. Eocenochelus does not share the morphology of the second and third vertebrals of the lower Miocene 'Podocnemis' aegyptiaca, which have lateral rounded protrusions anterior to the sulcus between the pleurals, the lateral margin of these vertebrals being markedly sinuous, and the second vertebral being significantly wider than the third.

The posterior plastral lobe, primitively narrower than the anterior, as in the oldest pleurodires (Lapparent de Broin and Murelaga, 1999; Lapparent de Broin et al., 2007; Pérez-García and Lapparent de Broin, 2015), is shared with 'Podocnemis' aegyptiaca, Turkanemys pattersoni and Erymnochelys madagascariensis, but not with 'Podocnemis' fajumensis and Kenyemys williamsi, taxa in which the width of both lobes is subequal. Eocenochelus lacks gular protrusions, which are well-developed in K. williamsi and in some 'P.' fajumensis specimens. The presence of a relatively long intergular in Eocenochelus, reaching back as far as the anterior margin of the entoplastron or overlying its the most anterior region, is not shared with K. williamsi or Er. madagascariensis. Eocenochelus shares with all of the described representatives of the Erymnochelys group, except for ' $P$.' fajumensis, the very short dorsal expansion of the plastral scute borders (also as in primitive oldest pleurodires) rather than the longer dorsal expansion present in other, more continental erymnochelyines. All Erymnochelys group members have an anterior lobe at least as long as half of its width, unlike the shorter and wider anterior lobes in the littoral Stereogenyina. Among the representatives of Eocenochelus, Eocenochelus farresi has the widest anterior lobe, which creates the narrowest axillary notches.

The youngest species of Eocenochelus, Eocenochelus farresi, has six neurals, a lesser 
TABLE 2. Comparison of shell characters of three representatives of the new European Eocene genus Eocenochelus recognized here: the lower Eocene Eocenochelus lacombianus sp. nov., the middle Eocene Eocenochelus eremberti comb. nov., and the upper Eocene Eocenochelus farresi sp. nov. For more information and detailed comparisons see the text.

\begin{tabular}{|c|c|c|c|}
\hline & Eo. eremberti & Eo. lacombianus & Eo. farresi \\
\hline Number of neurals & Al least 7 & 7 & 6 \\
\hline Width of the neurals & Relatively narrow for their length & $\begin{array}{l}\text { Relatively wide for their } \\
\text { length }\end{array}$ & $\begin{array}{l}\text { Relatively narrow for their } \\
\text { length }\end{array}$ \\
\hline Pubic scar & Long and narrow & Short and oval & Unknown \\
\hline $\begin{array}{l}\text { Posterior branch of the } \\
\text { ischiatic scar }\end{array}$ & Poorly-developed & $\begin{array}{l}\text { Well-developed in the } \\
\text { xiphiplastral point but not } \\
\text { reaching its extremity }\end{array}$ & $\begin{array}{l}\text { Well-developed, reaching } \\
\text { the xiphiplastral point } \\
\text { extremity }\end{array}$ \\
\hline Epiplastral symphysis & Relatively long & Relatively long & Very short \\
\hline Intergular anterior border & $\begin{array}{l}\text { Much narrower than that of each } \\
\text { gular }\end{array}$ & $\begin{array}{l}\text { Almost as wide as that of } \\
\text { each gular }\end{array}$ & $\begin{array}{l}\text { Almost as wide as that of } \\
\text { each gular }\end{array}$ \\
\hline $\begin{array}{l}\text { Latero-posterior region of } \\
\text { the humerals on the } \\
\text { hyoplastra }\end{array}$ & Relatively short overlap & Relatively short overlap & Long \\
\hline Posterior plastral lobe & $\begin{array}{l}\text { Relatively wide. Subrounded } \\
\text { lateral margins }\end{array}$ & $\begin{array}{l}\text { Narrow. Slightly concave } \\
\text { lateral margins }\end{array}$ & $\begin{array}{l}\text { Narrow. Slightly convex } \\
\text { lateral margins }\end{array}$ \\
\hline Anal notch & $\begin{array}{l}\text { Wide and short, the length being } \\
\text { about half of the width. Rounded } \\
\text { borders }\end{array}$ & $\begin{array}{l}\text { Wide and short, the length } \\
\text { being about half of the } \\
\text { width. Straight borders }\end{array}$ & $\begin{array}{l}\text { Deep, being almost as long } \\
\text { as wide. Rounded borders }\end{array}$ \\
\hline
\end{tabular}

number that those in the lower and middle Eocene representatives. The number of neurals is recognized as variable at interspecific level in Erymnochelyinae and, more specifically, in the European Neochelys (i.e., one of the few genera of Erymnochelyinae represented by several species, and the most diverse) (Lapparent de Broin, 2003b; Gaffney et al., 2011; Cadena, 2015a; Pérez-García and Lapparent de Broin, 2015). Thus, Neochelys arenarum is characterized by the presence of six neurals, the other known species having seven. As indicated, Eocenochelus lacombianus is characterized by the presence of seven neurals, and Eocenochelus eremberti has at least seven (see Table 2 and Figure 9). The presence of at least seven neurals has not been recognized in any representative of the Erymnochelys group. Thus, the other taxa (i.e., 'Podocnemis' fajumensis, 'Podocnemis' aegyptiaca, Turkanemys pattersoni, Kenyemys williamsi and Erymnochelys madagascariensis) have six neurals (a reduced neural number in relation to the primitive condition seen in oldest pleurodires), resulting in a medial contact between the sixth, seventh and eighth pairs of costals except in the case of $K$. williamsi, in which the contact occurs only between the last two pairs (as in Eo. lacombianus and, possibly, in Eo. eremberti).

The differences in size among the three specimens of Eocenochelus described here, and inter- preted as adults, may have specific value as in Neochelys (see Lapparent de Broin, 2003b; PérezGarcía and Lapparent de Broin, 2015). However, the analysis of a single shell of each species does not allow us to confirm this. Eocenochelus lacombianus, the smallest species, is wider than the other two species in relation to its length, which correlates with the relatively shorter neurals compared to their width relative to those in Eocenochelus eremberti and Eocenochelus farresi. The pubic scar of Eo. lacombianus, whose width is approximately half of its length, is much wider than that of Eocenochelus eremberti, which is almost five times longer than wide. The ischiatic scars of both Eo. lacombianus and Eocenochelus farresi have a well-developed posterior branch, that of Eo. lacombianus being close to the medial border of the anal notch and that of Eo. farresi being near the xiphiplastral tip.

The very short epiplastral symphysis of Eocenochelus farresi, less than one-fifth the length of the entoplastron, contrasts with that of Eocenochelus lacombianus and Eocenochelus eremberti, whose symphyses are approximately half the length of that element. The observed differences in the overlap of the intergular onto the entoplastron in the three specimens studied here (the intergular of the holotype of Eo. eremberti contacting the anterior margin of the element, that of Eo. lacombianus slightly overlapping its anterior region, and 
that Eo. farresi showing a greater overlap), are part of the range of variability known for the members of the Erymnochelys group including 'Podocnemis' fajumensis, Turkanemys pattersoni and Erymnochelys madagascariensis (Dacqué, 1912; Wood, 2003), although Eocenochelus has, as a whole, a less reduced intergular. However, the gular and intergular width and length with a defined margin of variability for each species are diagnostic characters in most of the extant and fossil Podocnemididae and Pelomedusidae.

The overlap of the humerals of Eocenochelus farresi onto the hyoplastra, the humero-pectoral sulci being located in the middle region of the epiplastra-hyoplastra sutures, is not only significantly higher than that in Eocenochelus lacombianus and Eocenochelus eremberti, but also higher than that of all the known specimens of the extinct species 'Podocnemis' fajumensis, 'Podocnemis' aegyptiaca, Turkanemys pattersoni and Kenyemys williamsi, and also the extant Erymnochelys madagascariensis. The anal overlap onto the xiphiplastron is moderate in Eocenochelus as in ' $P$.' fajumensis and ' $P$.' aegyptiaca, and as in most Pelomedusoides, but differing from Er. madagascariensis, T. pattersoni and $K$. williamsi which have a long overlap. Thus, the anal border length of these last three taxa, measured along the lateral border of the xiphiplastron, is at least two times the femoral border length, instead of being less than one and a half times longer than the femoral border in the representatives of Eocenochelus.

The lateral margins of the posterior plastral lobe of Eocenochelus eremberti are clearly subrounded. The posterior plastral lobes of both Eocenochelus lacombianus and Eocenochelus farresi are narrower, their lateral margins being only slightly concave in Eo. lacombianus and slightly convex in Eo. farresi. Thus, Eo. eremberti and Eo. farresi share with the continental erymnochelyines a tendency toward a laterally widened posterior lobe, but not the oldest species Eo. lacombianus.

Eocenochelus farresi has a deep, derived Ushaped anal notch, which is almost as long as wide and has a thick xiphiplastral point very close to its extremity. This condition is not shared with any other representative of the Erymnochelys group. The anal notch of Eocenochelus lacombianus is wide and much shorter, its length being less than half of its width, as is probably the anal notch of Eocenochelus eremberti (slightly incomplete posteriorly). This condition is similar to that present in the other members of the Erymnochelys group. Among the Pelomedusoides, the Eocenochelus species share the primitive participation of the ischiatic scar in the xiphiplastral posterior tip (a condition shared with several pleurodires, including the oldest forms, as well as the oldest chelids and Pelomedusoides) (longer in Eocenochelus lacombianus and Eocenochelus farresi and shorter in Eo. eremberti), while the ischiatic posterior tip is not at all (Erymnochelys madagascariensis, 'Podocnemis' fajumensis), or just barely ('Podocnemis' aegyptiaca), engaged in the xiphiplastral posterior tip (unknown in other species of the group; but being also restricted from the xiphiplastral point in stratigraphically younger and more derived taxa of these lineages).

\section{PALEOBIOGEOGRAPHICAL IMPLICATIONS AND CONCLUSIONS}

Neochelys was the only valid genus of Podocnemididae defined in the Paleogene of Europe. The new Eocenochelus represents the second European Paleogene genus of this lineage, both being members of Erymnochelyinae. This new genus is the only one that belongs to the Erymnochelys group in Europe (Figure 1). Therefore, the migration of at least two Erymnochelyinae clades from Africa to Europe, in the earliest Eocene or earlier, is confirmed here. Erymnochelyinae is not the only lineage of Pleurodira that arrived in Europe from Africa. Pleurodires are restricted to relatively warm regions, with a more limited geographical distribution than the members of Cryptodira. Pleurodires currently live in freshwater environments, usually in intertropical areas, on continents that formed part of Gondwana: Africa, South America and Oceania. The relative position of the landmasses, and variations in global temperatures, resulted in changes in their distributions. Thus, several lineages of African pleurodires are reported from Europe at levels deposited during periods characterized by relatively warm global temperatures (Broin, 1988; Lapparent de Broin, 2000b; Pérez-García and Lapparent de Broin, 2015; Pérez-García, 2016a). These migrations occurred in the late Cretaceous and Paleogene and were performed by Pelomedusoides, both Bothremydidae and Podocnemididae. Several lineages of bothremydids experienced diachronous migrations from Africa to Europe, at least from the Cenomanian (Pérez-García, 2016b), but were especially abundant and diverse in the uppermost Cretaceous when they became the dominant European faunas of freshwater turtles, particularly in the south of France and the Iberian Peninsula (Lapparent de Broin and Murelaga, 1999; Gaffney et al., 
2006; Pérez-García et al., 2012; Pérez-García and Lapparent de Broin, 2014). Podocnemididae is the most abundant and diverse family of Pleurodira in the European Cenozoic record. Neochelys is recognized in the lower, middle and upper Eocene record of several European countries, being represented by several species. This very abundant material is always found in continental environments, so it is recognized as a freshwater turtle. However, the new genus Eocenochelus, also recognized in the lower, middle and upper Eocene, is always found in coastal environments, and so is interpreted as a coastal marine form like some bothremydids. The extant Erymnochelys madagascariensis, and also all of the other extinct forms of the Erymnochelys group, are freshwater forms. Therefore, Eocenochelus is the only known member of this group not restricted to freshwater environments.

Eocenochelus represents the only known migration of members of the Erymnochelys group out of Africa. Although Africa is recognized as the origin-place of this group, with several potential Cretaceous ancestors being recognized, its origin is neither tightly dated nor geographically restricted. This group probably migrated from northern Africa at an unknown moment, crossing the Atlantic, united to the western Mediterranean Tethys. Africa and Europe (from Iberia to Italy) were separated by a marine space partly reduced by some intermediate lands, connected at regressive periods (not taken into account in the known paleogeographical maps, based on transgressive times) (see maps of the terminal Cretaceous and the Eocene in Blakey, 2016). During the Paleogene, transgressive events formed gulfs in the African and European coastal margins of the Atlantic connecting with the Mediterranean Tethys (Pomerol, 1973), thereby creating a route along the Ibero-French coastlines. All the Eocene localities yielding Eocenochelus species are situated in coastal environments, in the bottom of gulfs largely open on the Atlantic coasts at the deepest tansgressive stages. These are the Aquitanian gulf-Bay of Biscay, open nearly as eastward as the Mediterranean coast in the actual Aude French department at the late Ilerdian (middle Ypresian) when Eocenochelus lacombianus lived (Pomerol, 1973; Vignaux, 1975; Jaffrezo, 1977); the Parisian Basin gulf, open up to the French Marne department at the middle-upper Lutetian boundary when Eocenochelus eremberti lived (Pomerol, 1973, figure 3.14); and the Ebro Basin, largely open nearly up to the actual Catalan shore in the Osona district at the Priabonian, when Eocenochelus farresi lived (Vergéz and Burbank, 2008). The restricted distribution of the three studied species along the western European coast during the Eocene agrees with their attribution, based on comparative anatomy, to a single genus (i.e., Eocenochelus). Its appearance in Europe is slightly younger than that of its European erymnochelyine relative Neochelys, known from the earliest Eocene. Thus, both genera inhabited Europe during most of the Eocene, Neochelys living in continental environments and Eocenochelus being a littoral form.

Eocenochelus can be recognized as a podocnemidid without the particular shell acquisitions of Neochelys, the three species appearing to be not well adapted to continental environments by an enhanced protection of its head and members (as is the case of the representatives of Neochelys). The narrow plastron and the relatively short anterior peripheral border of the oldest one, Eocenochelus lacombianus, result in a less protected carapace, but with more space for limb movement. However, with its longer, unrounded anterior border, larger anterior lobe, and the slightly widened posterior lobes of Eocenochelus eremberti and Eocenochelus farresi, the shell of Eocenochelus was not as well adapted to a littoral way of life as were the littoral Sterogenyina of the Fayum (Egypt), Arabian Peninsula and America. Perhaps the relatively simple Eocenochelus pattern could facilitate its dispersal to Europe along the shores of that continent. Changes in the skull and lower jaw of Eocenochelus (these elements being only known for Eo. eremberti) in relation to those of the other members of the Erymnochelys group, such as a robust mandible and the complete absence of a cheek emargination, indicate a specialized feeding pattern, that cannot be determinated here considering the diversity of diets of the extant cheloniid species, although all of them have a similar secondary palate (Carr, 1952). Because Eocenochelus is the only member of this group not restricted to freshwater environments, but adapted instead to coastal marine ones, its masticatory characters could be interpreted as the result of adaptations to different feeding strategies linked to littoral environments. However, the extant Malagasy Erymnochelys madagascariensis, known for its diet consisting of freshwater plants, shares several skull adaptations with Eocenochelus (e.g., beak with long lower jaw symphysis, but less large; lateral cheek filling, but not complete), and also has a rather similar shell. It is not possible to establish if their feeding patterns, that may be adapted to dif- 
ferent foods, could be homoplastic or synapomorphic between both taxa. A better understanding of the systematic relationships of these and other forms will be necessary to provide meaningful new information on this and other issues. Thus, the littoral dispersion may not necessarily be responsible for these skull adaptations.

\section{ACKNOWLEDGEMENTS}

Authors thank F. Farrés and J. Altimiras (Geolab-Vic, Spain) and L. Lacombe (Ouveilhan, France), S. Calzada and A. Abad (MGSB, Spain), S. Chapman (Natural History Museum, , London), R. Gemel (Naturhistorisches Museum Wien, Wien), D. Marsal (Geolab-Vic), M. Leakey (NMK, Nairobi), G. López (Universitat Autònoma de Barcelona, Spain), R. Schoch and R. Wild (Staatliches Museum für Naturkunde Stuttgart, Stuttgart), and at MNHN, S. Bailon (Anatomie Comparée), L. Vives (Département des Galeries), R. Allain and N.-E. Jalil (Paléontologie), late P. Taugourdeau, R. Bour, A. Lalis, L. Pierre and B. Yves (Zoologie des Reptiles) for material access (both the fossil remains presented here and remains of numerous fossil and extant taxa with which we have conducted comparative studies); D. Merle (Paléontologie, MNHN) for stratigraphical information and the determination of the gastropods from Soulane; F. Farrés for stratigraphical information relative to the Spanish specimen studied here; P. Mocho (UNED) for the photos of the skull of Eocenochelus eremberti; and the Editors D. Hembree and J. Louys and two anonymous reviewers for comments and suggestions. The research activity of A. P.-G. is funded by the Ministerio de Economía y Competitividad (FPDI-2013-18986), Ministerio de Ciencia e Innovación (CGL2015-68363-P), and received support from several Synthesys projects (http:// synthesys3.myspecies.info/), financed by the European Community Research Infrastructure Action under the FP7 (BE-TAF-3202, BE-TAF-5271, FRTAF-4237 and GB-TAF-4187). The holotype of Eocenochelus farresi was discovered (at the early 1960s) and prepared in the frame of researches performed since the 1950s by the GLV group, Sciences section of the "Patronat d'Estudis Osonencs," now a delegation of the MGSB.

\section{REFERENCES}

Andrews, C.W. 1900. On a new species of chelonian (Podocnemis aegyptica) from the Lower Miocene of Egypt. Geological Magazine, 7:1-2.
Andrews, C.W. 1901. Preliminary note on some recently discovered extinct vertebrates from Egypt (Part II). Geological Magazine, 4:436-444.

Andrews, C.W. 1903. On some pleurodiran chelonians from the Eocene of the Fayum, Egypt. The Annals and Magazine of Natural History, 11:115-122.

Andrews, C.W. 1906. A descriptive catalog of the Tertiary Vertebrata of the Fayum, Egypt. Trustees of the British Museum (Natural History), London.

Antunes, M.T. and de Broin, F. 1988. Le Crétacé terminal de Beira Litoral, Portugal: remarques stratigraphiques et écologiques; étude complémentaire de Rosasia soutoi (Chelonii, Bothremydidae). Ciências da Terra, 9:153-200.

Aubry, M.P. 1986. Paleogene calcareous nannoplankton biostratigraohy of northwestern Europe. Palaeogeography, Palaeoclimatology, Palaeoecology, 55:267334.

Barbière, F. and Marivaux, L. 2015. Phylogeny and evolutionary history of hystricognathous rodents from the Old World during the Tertiary; new insights into the emergence of the modern 'phiomorph' families, $p$. 87-138. In Cox, P.G. and Hautier, L. (eds.), Evolution of the Rodents 5: Advances in Phylogeny, Functional Morphology and Development. Cambridge University Press, UK.

Bergounioux, F.-M. 1954. Les Chéloniens fossiles des terrains tertiaires de la Vénétie. Memorie degli istituti di Geologica e Mineralogia dell'Università di Padova, 18:1-115.

Blakey, R. 2016. Colorado Plateau Geosystems. Deep Time Maps Website, Arizona, USA.

Brongniart, A. 1800. Essai d'une classification naturelle des reptiles. Bulletin des Sciences, par la Société Philomatique, 2:81-82.

Cadena, E. 2015a. A global phylogeny of Pelomedusoides turtles with new material of Neochelys franzeni Schleich, 1993 (Testudines, Podocnemididae) from the middle Eocene, Messel Pit, of Germany. PeerJ 3, e1221:1-27.

Cadena, E. 2015b. The first South American sandownid turtle from the Lower Cretaceous of Columbia. PeerJ 3, e1431:1-24.

Carr, A. 1952. Handbook of Turtles. The Turtles of the United States, Canada and Baja California. Comstock Publications, Cornell University Press, New York.

Cope, E.D. 1864. On the limits and relations of the Raniformes. Proceedings of the Academy of Natural Sciences of Philadelphia, 16:181-183.

Cope, E.D. 1868. On the origin of genera. Proceedings of the Academy of Natural Sciences of Philadelphia, 20:242-300.

Dacqué, E. 1912. Die fossilen Schildkröten Aegyptens. Neues Jahrbuch für Geologie und Paläontologie, 14:275-337.

de Broin, F. 1977. Contribution à l'étude des Chéloniens. Chéloniens continentaux du Crétacé et du Tertiaire 
de France. Mémoires du Muséum national d'Histoire naturelle, 38:1-366.

de Broin, F. 1980. Les Tortues de Gadoufaoua (Aptien du Niger); aperçu sur la paléobiogéographie des Pelomedusidae (Pleurodira). Mémoires de la Société géologique de France, 139:39-46.

de Broin, F. 1988. Les tortues et le Gondwana. Examen des rapports entre le fractionnement du Gondawana et la dispersion géographique des tortues pleurodires à partir du Crétacé. Studia Geologica Salmanticensia, Studia Palaeocheloniologica, 2:103-142.

de Broin, F., Buffetaut, E., Koeniguer, J.-C., Rage, J.-C., Russell, D., Taquet, P., Vergnaud-Grazzini, C. and Wenz, S. 1974. La faune de vertébrés continentaux du gisement d'In Beceten (Sénonien du Niger). Compte rendu sommaire et Bulletin de la Société Géologique de France, 279:469-472.

Ellenberger, F., Freytet, P., Plaziat, J.-C., Bessière, G., Viallard, P., Berger, G.-M., and Marchal, J.-P. 1987. Notice explicative de la feuille Capendu à 1/50000. Bureau des Recherches Géologiques et Minières, Orléans.

Ferreira, G.S., Rincón, A.D., Solórzano, A., and Langer, M.C. 2015. The last marine pelomedusoids (Testudines: Pleurodira): a new species of Bairdemys and the paleoecology of Stereogenyina. PeerJ. doi:10.7717/peerj.1063.

Fitzinger, L.J. 1843. Systema Reptilium. Fasciculus Primus: Amblyglossae. Vondobonae. Braumuller und Seidel, Vienna.

Fourteau, R. 1920. Contribution à l'étude des vertébrés miocènes de l'Egypte. Government Press, Cairo.

Gaffney, E.S. and Forster, C.A. 2003. Side-necked turtle lower jaws (Podocnemididae, Bothremydidae) from the Late Cretaceous Maevarano Formation of Madagascar. American Museum Novitates, 3397:1-13.

Gaffney, E.S. and Wood, R.C. 2002. Bairdemys, a new side-necked turtle (Pelomedusoides: Podocnemididae) from the Miocene of the Caribbean. American Museum Novitates, 3359: 1-28.

Gaffney, E.S., Meylan, P.A., Wood, R.G., Simons, E., and Almeida Campos, D. de. 2011. Evolution of the sidenecked turtles: the family Podocnemididae. Bulletin of the American Museum of Natural History, 350:1237.

Gaffney, E.S., Tong, H., and Meylan, P.A. 2006. Evolution of the side-necked turtles: the families Bothremydidae, Euraxemydidae, and Araripemydidae. Bulletin of the American Museum of Natural History, 300:1-700.

Gély, J.-P. 2009. Le Lutétien: une période charnière de l'histoire du Bassin Parisien. Saga Information, 284:6-24.

Grandidier, A. 1867. Liste des reptiles nouveaux découverts, en 1866, sur la côte sud-ouest de Madagascar. Revue et Magasin de Zoologie Pure et Appliquée, 19:232-234.
Jaffrezo, M. (coord.). 1977. Pyrénées orientales, Corbières. Guides géologiques régionaux. Masson et Cie éditeurs, Paris.

Klein, N., Bussert, R., Evans, D., Salih, K.A.O., Eisawi, A.A.M., Nafi, M., and Müller, J. in press. Turtle remains from the Wadi Milk Formation (Upper Cretaceous) of Northern Sudan. Palaeobiodiversity and Palaeoenvironments. doi: 10.1007/s12549-015-0225-9.

Lapparent de Broin, F. de. 2000a. The oldest pre-Podocnemidid turtle (Chelonii, Pleurodira), from the early Cretaceous, Ceará state, Brasil, and its environment. Treballs del Museu de Geologia de Barcelona, 9:4395.

Lapparent de Broin, F. de. 2000b. African chelonians from the Jurassic to the Present: Phases of development and preliminary catalogue of the fossil record. Palaeontologia Africana, 36:43-82.

Lapparent de Broin, F. de. 2003a. Miocene Chelonians from southern Namibia. Memoir of the Geological Survey of Namibia, 19:67-102.

Lapparent de Broin, F. de. 2003b Neochelys sp. (CheIonii, Erymnochelyinae), from Silveirinha, early Eocene, Portugal. Ciências da Terra, 15:117-132.

Lapparent de Broin, F. de. and Murelaga, X. 1999. Turtles from the Upper Cretaceous of Laño (Iberian Peninsula). Estudios del Museo de Ciencias Naturales de Alava, 14:135-211.

Lapparent de Broin, F. de. and Werner, C. 1998. New Late Cretaceous turtles from the Western Desert, Egypt. Annales de Paléontologie, 84:131-214.

Lapparent de Broin, F. de, de la Fuente, M.S. and Fernandez, M. 2007. Notoemys (Chelonii, Pleurodira), Late Jurassic of Argentina: new examination of the anatomical structure and comparisons. Revue de Paléobiologie, 26: 99-136.

Lapparent de Broin, F. de, Lange-Badré, B., and Dutrieux, M. 1996. Nouvelles découvertes de tortues dans le Jurassique supérieur du Lot (France) et examen du taxon Plesiochelyidae. Revue de Paléobiologie, 15:533-570.

Lapparent de Broin, F. de., Murelaga Bereikua, X., and Codrea, V. 2004. Presence of Dortokidae (Chelonii, Pleurodira) in the earliest Tertiary of the Jibou Formation, Romania: Paleobiogeographical implications. Acta Palaeontologica Romaniae, 4:203-215.

Latreille, P.A. 1800. Histoire naturelle des Salamandres de France, précédée d'un tableau méthodique des autres reptiles indigènes. Villier, Paris.

Merle, D. (coord.). 2008. Stratotype Lutétien. Collection Patrimoine géologique, Editions MNHN \& Biotopes (Paris \& Mèze).

Murelaga, X., Lapparent de Broin, F. de, Farrés, F., Altimiras, J., and López, G. 2007. Tortugas marinas del Eoceno superior (Bartoniense) de la Comarca de Vic (Provincia de Barcelona, NE de la Cuenca del Ebro), p. 163-164. In Graga, J.C., Checa, A., and Company, M. (eds.), Abstract book of the XXIII Jornadas de la 
Sociedad Española de Paleontología. Sociedad Española de Paleontología, Spain.

Pérez-García, A. 2014. Finding the supposedly lost holotype and only known specimen of the podocnemidid Stereogenys libyca, a turtle from the early Oligocene of Egypt, p. 136. In Pankhurst, R.J., Castiñeiras, P., and Sánchez Martínez, S. (eds.), Abstract Book of Gondwana 15, North Meets South. Sociedad Geológica de España, Madrid.

Pérez-García, A. 2016a. A new turtle confirms the presence of Bothremydidae (Pleurodira) in the Cenozoic of Europe and expands the biostratigraphic range of Foxemydina. The Science of Nature, 103:50.

Pérez-García, A. 2016b. A new turtle taxon (Podocnemidoidea, Bothremydidae) reveals the oldest known dispersal event of the crown Pleurodira from Gondwana to Laurasia. Journal of Systematic Palaeontology, 2016: 1-23.

Pérez-García, A. and Lapparent de Broin, F. de. 2013. A new species of Neochelys (Chelonii, Podocnemididae) from the Ypresian (early Eocene) of the south of France. Comptes Rendus Palevol, 12:269-277.

Pérez-García, A. and Lapparent de Broin, F. de. 2014. An update on the diachronous migration to Europe of several Gondwanan lineages of pleurodiran turtles, p. 137. In Pankhurst, R.J., Castiñeiras, P., and Sánchez Martínez, S. (eds.), Abstract Book of Gondwana 15, North Meets South. Sociedad Geológica de España, Madrid.

Pérez-García, A. and Lapparent de Broin, F. de. 2015. New insights into the anatomy and systematic of 'Papoulemys' laurenti, a representative of Neochelys (Chelonii, Podocnemididae) from the early Eocene of the south of France. Paläontologische Zeitschrift, 89:901-923.

Pérez-García, A., Ortega, F., and Murelaga, X. 2012. A new genus of Bothremydidae (Chelonii, Pleurodira) in the Cretaceous of Southwestern Europe. Geobios, 45:219-229.

Plaziat, J.-C. 1984a. Le domaine pyrénéen de la fin du Crétacé à la fin de l'Eocene. Stratigraphie, paléoenvironnements et évolution paléogéographique. ParisSud, Paris.

Plaziat, J.-C. 1984b. Paléobiocénoses et déplacements massifs d'organismes littoraux (madréporaires, mollusques, fruits de Nypa) en sédimentation vasosableuse péri-deltaïque. Rôle des corants, des tempêtes et des séismes dans l'llerdien de Coustouge (Aude, France). Geobios, 8:301-312.

Pomerol, C. 1973. Stratigraphie et Paléogéographie. Ere Cénozoïque (Tertiaire et Quaternaire). Doin, Paris.

Pritchard, P.C.H. 1979. Encyclopedia of Turtles. Neptune, New Jersey.

Ramsay, E.P. 1886. On a new genus and species of fresh water turtle from the Fly River, New Guineea. Proceedings of the Linnean Society of New Wales, 1:158-162.

Renous, S., Lapparent de Broin, F. de, Depecker, M., Davenport, J., and Bels, V. 2008. Evolution of Loco- motion in Aquatic Turtles, p. 97-138. In Wyneken, J., Godfrey, M.H., and Bels, V. (eds.), Biology of Turtles: From Structures to Strategies of Life. CRC Press, New York.

Righi, D. and Delfino, M. 2003. Erymnochelys sp.: una tartaruga 'malgascia' nel Paleogene della Sardegna, p. 44. In Pavia, M. and Violanti, D. (eds.), Riassunti e Programma delle Giornate di Paleontologia 2003. Alessandria.

Sanjuan, J., Martín-Closas, C., Serra-Kiel, J., and Gallardo, H. 2012. Stratigraphy and biostratigraphy (charophytes) of the marine-terrestrial transition in the Upper Eocene of the NE Ebro Basin (Catalonia, Spain). Geologica Acta, 10:1-13.

Schweigger, A.F. 1812. Prodromus monographiae CheIoniorum, Pt. 1. Königsberger Archiv. für Naturwissenschaft und Mathematik, 1812:271-458.

Swinton, W.E. 1939. A new fresh-water tortoise from Burma. Records of the Geological Survey of India, 74:548-551.

Taugourdeau, P. 1951. Nouvelle coupe géologique de la Terrasse de Saint-Germain-en-Laye (Seine-et-Oise). Cahiers Géologiques de Thoiry, 8:72.

Taugourdeau, P. 1965. Podocnemys eremberti nov. sp., Chélonien pleurodire du Lutétien de St-Germain-enLaye (Seine-et-Oise). Compte-rendu sommaire et bulletin de la Société Géologique de France, 5:165.

Thomas, H., Roger, J., Sen, S., Dejax, J., Schuler, M., Al-Sulaimani, Z., Bourdillon de Grissac, C., Breton, G., Broin, F. de, Camoin, G., Cappetta, H., Carriol, R.P., Cavelier, C., Chaix, C., Crochet, J.-Y., Farjanel, G., Gayet, M., Gheerbrant, E., Lauriat-Rage, A., Noel, D., Pickford, M., Poignant, A.F., Rage, J.-C., Roman, J., Rouchy, J.-M., Secretan, S., Sige, B., Tassy, P., and Wenz, S. 1991. Essai de reconstitution des milieux de sédimentation et de vie des primates anthropoïdes de l'Oligocène de Taqah (Dhofar, Sultanat d'Oman). Bulletin de la Société géologique de France, 162:713-724.

Tong, H. and Meylan, P. 2013. Morphology and Relationships of Brachyopemys tingitana gen. et sp. nov. from the Early Paleocene of Morocco and Recognition of the New Eucryptodiran Turtle Family: Sandownidae, p. 187-212. In Brinkman, D., Holroyd, P., and Gardner, J. (eds.), Morphology and Evolution of Turtles. Vertebrate Paleobiology and Paleoanthropology, Springer, Nederland.

Tronc, E. and Vuillemin, S. 1973. Contribution à l'étude de la faune endémique malgache: étude ostéologique de Erymnochelys madagascariensis Grandidier, 1867 (Chélonien, Pelomedusidae). Bulletin de l'Académie Malgache, 51:189-220.

Vergéz, J. and Burbank, D.W. 2008. Thrusting and basin configuration in the eastern and central Pyrenees (Spain), p. 121-133. In Friend, P. and Dabrio, C. (eds.), Tertiary basins of Spain. Cambridge University Press, UK.

Vigneaux, M. 1975. Aquitaine. Guides Géologiques Régionaux. Masson et Cie, Paris. 
von Reinach, A. 1903. Schildkrötenreste aus dem ägyptischen Tertiär. Abhandlungen der Senckenbergischen Naturforschenden Gesellschaft, 29:1-64.

Wagler, J. 1830. Natürliches System der Amphibien, mit vorangehender Classification der Säugthiere und Vögel. J.G. Cotta, Munich, Stuttgart and Tübingen.

Weems, R.E. and Knight, J.L. 2013. A new species of Bairdemys (Pelomedusoides: Podocnemididae) from the Oligocene (Early Chattian) Chandler Bridge Formation of South Carolina, USA, and its paleobiogeographic implications for the genus, p. 289-303. In Brinkman, D., Holroyd, P., and Gardner, J. (eds.), Morphology and Evolution of Turtles. Vertebrate Paleobiology and Paleoanthropology, Springer, Nederland.

White, C. 2013. Corals and climate change in the Cenozoic; a case study based on the staghorn coral Acropora. Unpublished PhD Thesis, Royal Holloway University of London, UK.

Williams, E.E. 1954. New or redescribed pelomedusid skulls from the Tertiary of Africa and Asia (Testu- dines, Pelomedusidae) 1. Dacquemys paleomorpha, new genus, new species from the Lower Oligocene of the Fayum, Egypt. Breviora, 35:1-9.

Wood, R.C. 1970. A review of the fossil Pelomedusidae (Testudines, Pleurodira) of Asia. Breviora, 357:1-24.

Wood, R.C. 1983. Kenyemys williamsi, a fossil pelomedusid turtle from the Pliocene of Kenya, p. 74-85. In Rhodin, G.J. and Miyata, K. (eds.), Advances in herpetology and evolutionary biology. Museum of Comparative Zoology, Cambridge.

Wood, R.C. 2003. Fossil turtles from Lothagam, p. 115136. In Leakey, M.G. and Harris, J.M. (eds.), Lothagam: the dawn of humanity in eastern Africa. Columbia University Press, New York.

Wood, R.C. and Díaz de Gamero, M. L. 1971. Podocnemis venezuelensis, a new fossil pelomedusid (Testudines, Pleurodira) from the Pliocene of Venezuela and a review of the history of Podocnemis in South America. Breviora, 376:1-23. 